\title{
Freshwater salinization syndrome: from emerging global problem to managing risks
}

\author{
Sujay S. Kaushal • Gene E. Likens • Michael L. Pace • Jenna E. Reimer • \\ Carly M. Maas · Joseph G. Galella $\cdot$ Ryan M. Utz $\cdot$ Shuiwang Duan • \\ Julia R. Kryger • Alexis M. Yaculak • Walter L. Boger • Nathan W. Bailey • \\ Shahan Haq · Kelsey L. Wood · Barret M. Wessel • Cedric Evan Park • \\ Daniel C. Collison • Belie Y.'aaqob I. Aisin • Taylor M. Gedeon • \\ Sona K. Chaudhary · Jacob Widmer • Charles R. Blackwood • Claire M. Bolster • \\ Matthew L. Devilbiss • Diego L. Garrison - Sharon Halevi • Gannon Q. Kese • \\ Emily K. Quach • Christina M. P. Rogelio • Maggie L. Tan • Henry J. S. Wald • \\ Seyram A. Woglo
}

Received: 17 March 2021 / Accepted: 18 March 2021/Published online: 12 April 2021

(C) The Author(s) 2021

\begin{abstract}
Freshwater salinization is an emerging global problem impacting safe drinking water, ecosystem health and biodiversity, infrastructure corrosion, and food production. Freshwater salinization originates from diverse anthropogenic and geologic sources including road salts, human-accelerated weathering, sewage, urban construction, fertilizer, mine drainage, resource extraction, water softeners, saltwater intrusion, and evaporative concentration of
\end{abstract}

Responsible Editor: Robert Howarth.

This paper is an invited contribution to the 35th Anniversary Special Issue, edited by Sujay Kaushal, Robert Howarth, and Kate Lajtha.

S. S. Kaushal $(\bowtie) \cdot$ J. E. Reimer · C.

M. Maas · J. G. Galella · S. Duan ·

J. R. Kryger · A. M. Yaculak · W. L. Boger .

N. W. Bailey · S. Haq · K. L. Wood ·

D. C. Collison · B. Y.'aaqobI. Aisin

S. K. Chaudhary · J. Widmer · M. L. Tan

Department of Geology, University of Maryland,

College Park, MD, USA

e-mail: skaushal@umd.edu

S. S. Kaushal - J. E. Reimer - C. M. Maas .

J. G. Galella · S. Duan · J. R. Kryger ·

A. M. Yaculak · W. L. Boger · N. W. Bailey · ions due to hydrologic alterations and climate change. The complex interrelationships between salt ions and chemical, biological, and geologic parameters and consequences on the natural, social, and built environment are called Freshwater Salinization Syndrome (FSS). Here, we provide a comprehensive overview of salinization issues (past, present, and future), and we investigate drivers and solutions. We analyze the expanding global magnitude and scope of FSS including its discovery in humid regions, connections to human-accelerated weathering and mobilization of 'chemical cocktails.' We also present data illustrating: (1) increasing trends in salt ion concentrations in some of the world's major freshwaters, including critical drinking water supplies; (2) decreasing trends in

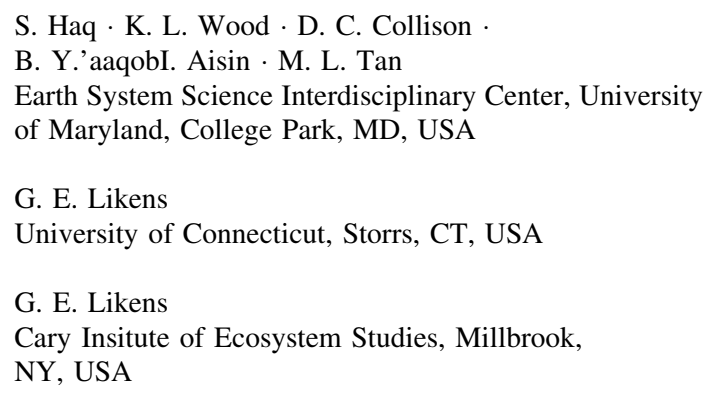


nutrient concentrations in rivers due to regulations but increasing trends in salinization, which have been due to lack of adequate management and regulations; (3) regional trends in atmospheric deposition of salt ions and storage of salt ions in soils and groundwater, and (4) applications of specific conductance as a proxy for tracking sources and concentrations of groups of elements in freshwaters. We prioritize FSS research needs related to better understanding: (1) effects of saltwater intrusion on ecosystem processes, (2) potential health risks from groundwater contamination of home wells, (3) potential risks to clean and safe drinking water sources, (4) economic and safety impacts of infrastructure corrosion, (5) alteration of biodiversity and ecosystem functions, and (6) application of high-frequency sensors in state-of-the art monitoring and management. We evaluate management solutions using a watershed approach spanning air, land, and water to explore variations in sources, fate and transport of different salt ions (e.g. monitoring of atmospheric deposition of ions, stormwater management, groundwater remediation, and managing road runoff). We also identify tradeoffs in management approaches such as unanticipated retention and release of chemical cocktails from urban stormwater management best management practices (BMPs) and unintended consequences of alternative deicers on water quality. Overall, we show that FSS has direct and indirect effects on mobilization of diverse chemical cocktails of ions, metals, nutrients, organics, and radionuclides in freshwaters with mounting impacts. Our comprehensive review suggests what could happen if FSS were not managed into the future and

M. L. Pace

Department of Environmental Sciences, University of Virginia, Charlottesville, VA, USA

R. M. Utz

Chatham University, Gibsonia, PA, USA

B. M. Wessel - C. E. Park - C. R. Blackwood .

M. L. Devilbiss - S. Halevi - G. Q. Kese ·

E. K. Quach · C. M. P. Rogelio .

H. J. S. Wald · S. A. Woglo

Department of Environmental Science and Technology, University of Maryland, College Park, USA

T. M. Gedeon

Department of Anthropology, University of Maryland,

College Park, USA evaluates strategies for reducing increasing risks to clean and safe drinking water, human health, costly infrastructure, biodiversity, and critical ecosystem services.

Keywords Nonpoint source pollution - Emerging contaminants - Aquatic life - Human health ·

Infrastructure $\cdot$ Corrosion $\cdot$ Safe drinking water

\section{Introduction}

Freshwater salinization is an emerging water quality problem across the globe and is becoming a major chemical signature of the Anthropocene (Kaushal et al. 2005, 2018a, 2019; Cañedo-Argüelles et al. 2013a, 2016b; Stets et al. 2018). Although approximately $70 \%$ of Earth is covered by water, only about $2.5 \%$ of that is freshwater (Trenberth et al. 2007). While freshwater contains major ions originating from natural salts and mineral sources, dramatic increases in salt ion concentrations are occurring in fresh waters across local, regional, continental, and global scales (Kaushal et al. 2005, 2013, 2018a; Anning and Flynn 2014; Dugan et al. 2017; Stets et al. 2018). Increases are due to human activities including, but not limited to: urbanization, accelerated weathering of rocks by acid rain, weathering of impervious surfaces, agricultural fertilizers, hydrologic alterations, irrigation and evaporative concentration, resource extraction, land clearing, saltwater intrusion, and application of road salts. When major ion concentrations exceed pollution

C. M. Bolster

Department of Biology, University of Maryland,

College Park, USA

D. L. Garrison

Environmental Science \& Policy Program, University of Maryland, College Park, USA 
thresholds (and/or interact with complex environmental factors) there can be degradation of agricultural soils, drinking water, biodiversity, and infrastructure, which represent risks to environment, human health, and infrastructure (Cañedo-Argüelles et al. 2016b; Kaushal 2016; Iglesias 2020; Lopatina et al. 2021). The complex interrelationships between salt ions and chemical, biological, and geologic parameters and consequences on the natural, social, and built environment is called Freshwater Salinization Syndrome (FSS). In order to face the challenge of increasing impacts from freshwater salinization, a better understanding is needed about the diverse causes of freshwater salinization and the various environmental consequences of different mixtures of salt ions (as impacted by anthropogenic watershed salt inputs, saltwater intrusion, and/or other processes) (Kaushal et al. 2018a, 2019, 2020). In the future, many of the world's water resources may be impacted by watershed salt inputs and also from saltwater intrusion into watersheds (Tully et al. 2019a). Long-term trends suggest that without urgent action, FSS will continue to cause increases in salinity and shift ionic compositions across local, regional, and global scales (Kaushal et al. 2005, 2013, 2017, 2018a; Stets et al. 2018; Kaushal et al. 2019; Stets et al. 2020; Kaushal et al. 2020). Consequently, these trends show that there is a need to accurately identify emerging causes of freshwater salinization and to strategically focus management approaches. Here, we analyze the rapidly expanding scope and magnitude of FSS, identify critical research issues, and propose and evaluate management strategies.

\section{What is freshwater salinization syndrome?}

On a global scale, increasing salinization from a diversity of causes has been occurring over a century without recognition and regulation equivalent to other global water pollution issues such as acid rain, eutrophication, and mine drainage, despite broad impacts to society and the environment (Kaushal et al. 2019; Iglesias 2020). Salinization typically refers to an accumulation of ions yielding an increase in electrical conductivity and/or total dissolved solids (Feistel et al. 2015); it is important to note that conductivity is not equal to total dissolved solids, but it can be a useful field proxy (as addressed later). The interrelationships between salt ions and chemical, biological, and geological parameters and consequences in the natural and built environment are called Freshwater Salinization Syndrome (Kaushal et al. 2018a, 2019). The FSS encompasses a variety of processes such as sodification, the increase in exchangeable sodium in a soil, expressed as exchangeable sodium percentage (ESP) or as sodium adsorption ratio. The FSS can influence alkalinization (Kaushal et al. 2013), which is an increase in alkalinity or the ability of a solution to neutralize acids due to bicarbonate and carbonate, bisulfide, hydroxides, and other ions (Drever 1988). The FSS also encompasses changes in microbial biogeochemical processes, corrosion potential, colligative properties of water, and other chemical and biological interactions, which have only recently been recognized (Kaushal et al. 2019, 2020). Diverse causes, interrelationships, and consequences linked to salinization can be organized at a systems level using the conceptual model of FSS. The FSS links salinization, sodification, alkalinization, and other environmental processes as controlled by inputs of multiple ions from both anthropogenic and geological sources such as $\mathrm{Na}^{+}, \mathrm{Ca}^{2+}, \mathrm{Mg}^{2+}, \mathrm{K}^{+}$, $\mathrm{NO}_{3}{ }^{-}, \mathrm{SO}_{4}{ }^{2-}, \mathrm{Cl}^{-}, \mathrm{Br}^{-}$, etc. and secondary mobilization of other elements $(\mathrm{Sr}, \mathrm{Cu}, \mathrm{Mn}, \mathrm{Cd}, \mathrm{Zn}, \mathrm{Pb}$, radionuclides etc.) into chemical cocktails (Kaushal et al. 2019, 2020; Lazur et al. 2020). The FSS and its direct and indirect effects has far reaching implications for surface, ground and drinking water quality, and aquatic and terrestrial ecosystem function, human health, food production, and degradation of infrastructure.

\section{Part 1. Expanding magnitude and scope of freshwater salinization}

Our goal for this first section is to acknowledge the traditional bias in salinization research in arid and semi-arid regions, and introduce the additional need for a new focus on humid environments. We also include our perspective from documenting widespread salinization in humid regions and links to drinking water over almost 20 years of research (Kaushal et al. 2018b), while also documenting other literature. There are many topics that are introduced in this first section, especially the use of deicing salts and human-accelerated weathering, which are discussed further in later 
sections. The main goal of this section is to justify the need for a new conceptual framework for Freshwater Salinization Syndrome in humid environments, while highlighting its diverse causes and consequences. Overall, we introduce many reasons to study, monitor, and manage freshwater salinization in a more holistic way using a syndrome approach.

Historical focus on salinization in arid and semiarid regions

There has long been concern about freshwater salinization as a serious environmental problem locally in arid and semi-arid regions since the time of ancient civilizations. For example, in ancient Mesopotamia, $\mathrm{Na}^{+}$from the northern mountains was carried by rivers for irrigation and led to salt accumulation in soils due to the semi-arid climate, low soil permeability, and ancient marine geologic transgressions (Jacobsen and Adams 1958). Salinization of soils made land barren and contributed to the collapse of some of the world's major civilizations throughout human history (Jacobsen and Adams 1958). Some of these regions never fully recovered from salinization effects on agriculture due to low groundwater tables, poor drainage, and excessive irrigation.

There are many diverse processes that contribute to salinization in arid and semiarid areas. For example, much historical work has focused on diverse causes of salinization of rivers and lakes (e.g. Colorado River, Jordan River, Aral Sea, Lake Chad) in arid and semiarid regions, and salinization has been considered an important syndrome of the Anthropocene (Pillsbury 1981; Meybeck and Helmer 1989; Kreitler 1993; Meybeck 2003; Vengosh 2005). As just one illustrative example of dryland salinization from Australia, irrigation leaves behind salt residues after evaporation and rising groundwater levels following vegetation removal, thereby bringing salt ions from weathering of parent material toward the soil surface (Williams 1987; Cañedo-Argüelles et al. 2013a; Iglesias 2020). When trees or native vegetation are removed, evapotranspiration decreases and water tables rise into the capillary fringe. Salt ions are translocated by capillary movement up the unsaturated zone and then concentrated by evaporation. Salt ion accumulation occurs near soil surface horizons making the soils more sodic. When trees and deep-rooted vegetation are present, groundwater tables are lower and dissolved ions may not reach up to the capillary fringe towards soil surfaces. Thus, salt ions can be diluted and removed by deeper groundwater flowpaths. The size of soil micropores, texture of soils (clay vs. sand), bedrock and weathering rates, and hydraulic conductivity all affect the speed of capillary rise of groundwater and salt ions and the vulnerability to salinization. Given much previous work understanding salinization processes in arid and semi-arid regions (Pillsbury 1981; Meybeck and Helmer 1989; Kreitler 1993; Meybeck 2003; Vengosh 2005), we focus our review and analysis on humid regions where causes, consequences, and conceptual frameworks related to freshwater salinization are not as well studied.

Discovery of widespread freshwater salinization in humid regions

Freshwater salinization is now increasingly recognized as a serious and widespread environmental issue in humid regions with diverse causes and consequences (Kaushal et al. 2018a, 2019). Freshwater salinization of inland waters has a long history of being recognized as an important source of water quality degradation on a case study basis, and especially in certain geographic regions (particularly coastal regions). For example, the International Commission for the Protection of the Rhine was formed in 1950, partially over salinization concerns that were ultimately related to mining and industrial activities (Meybeck and Helmer 1989). Additionally, the study of saltwater intrusion has a very long and extensive history, with the first published reference possibly being from 1855 in England (Braithwaite 1855; Kashef 1972) (we allude to this history in a later section on saltwater intrusion).

Across inland regions, one major cause of salinization, studied intensively, has been road salt use (e.g. Kaushal et al. 2005; Corsi et al. 2010; Dugan et al. 2017; Stets et al. 2018). During the winter of 1941-1942, New Hampshire became the first state in the U.S. to employ a statewide policy of incorporating road salting as part of its weather management protocol, dispersing about 4500 metric tons of salt on high-priority roads (National Research Council 1991). Following World War II, as the societal and commercial importance of the rapidly expanding highway system developed, road salt use soared nationwide, doubling every 5 years during the 1950 s 
and 1960s (National Research Council 1991). Prior to widespread road salt use, abrasives had been the most commonly employed technique, and motorists were generally encouraged to avoid unnecessary travel. Annual road salt sales in the U.S. have increased from 280,000 metric tons per year in the 1940 s to 16.0 million metric tons per year from 2000 to 2008 (Corsi et al. 2010).

While salinization of freshwater systems due to road salt use had been identified as early as the 1960 's, the regional issue of freshwater salinization did not reach mainstream awareness until the mid-2000's. Early work showed that freshwater salinization was mostly a localized issue influencing individual aquatic ecosystems (Bubeck et al. 1971; Huling and Hollocher 1972; Godwin et al. 2003). During the mid-2000's, our work was the first to demonstrate that freshwater salinization was a serious and very widespread regional environmental issue in the Northeastern U.S. including impacts on major drinking water supplies, such as rapidly increasing chloride concentrations over time (Jackson and Jobbagy 2005; Kaushal et al. 2005). Our early work documented strong statistical relationships between increased $\mathrm{Cl}^{-}$ concentrations in streams with increasing watershed impervious surface cover (Kaushal et al. 2005). In addition, we showed that $\mathrm{Cl}^{-}$concentrations not only reached extremely high levels (25-40\% the salinity of seawater) during winter months due to road salts, but that $\mathrm{Cl}^{-}$concentrations remained significantly elevated year round (Kaushal et al. 2005). These results suggested that $\mathrm{Cl}^{-}$and salt ions were being retained in soils and groundwater and that the hydrologic residence time of salt ions could be considerably longer than previously expected (Shaw et al. 2012; Cooper et al. 2014). For example, groundwater has been salinized by road salts over the past 100 years in the US (Cassanelli and Robbins 2013). Salt can be retained in watersheds over time in soils and groundwater (Kaushal et al. 2005; Kelly et al. 2008) and this retention drives the long-term increasing trends over all seasons. Even if road salt use decreased, salt ions would not be flushed out for decades (Kaushal et al. 2005; Kelly et al. 2019), leaving a strong legacy effect of road salts on ecosystems.

Other studies have also demonstrated high levels of salt concentrations during winter months and widespread salinization in different regions of North America (Dugan et al. 2017, 2020). For example, winter concentrations of $\mathrm{Cl}^{-}$were elevated above the United States Environmental Protection Agency (USEPA) acute aquatic life water-quality criteria concentration of $860 \mathrm{mg} / \mathrm{L}$ and above the USEPA chronic aquatic life water-quality criteria concentration of $230 \mathrm{mg} / \mathrm{L}$ in streams of the Midwestern USA, indicating potential for toxicity effects to aquatic life (Corsi et al. 2010). Increases in long-term $\mathrm{Cl}^{-}$ concentrations were highest in developed areas, contributing to episodic and potential long-term detrimental impacts of road salt on both water quality and aquatic life (Corsi et al. 2010). In the past, comprehensive results on the potential impacts to sources of drinking water and human health were less studied and considered. Other notable studies in New York, New Hampshire, Texas, Puerto Rico, and other locations in the USA also demonstrated increasing trends in sodium and chloride concentrations due to a variety of causes, in addition to road salt (Steele and Aitkenhead-Peterson 2011; Potter et al. 2014; Kaushal et al. 2020). The increasing $\mathrm{Cl}^{-}$trends discovered in this first phase of FSS research (e.g. earlier published papers by our group and also the growing literature by others investigating impacts of road salt) also raised concerns about drinking water safety and increased corrosion potential; for example, salinization can increase the chloride to sulfate mass ratio, which is a common index of corrosion potential in pipes, and can enhance leaching of $\mathrm{Pb}$ and other metals into drinking water (Kaushal 2016; Stets et al. 2018; Pieper et al. 2018). Although the widespread use of road salts is a dominant factor leading to freshwater salinization in many regions, there is also a clear link between urbanization and the potential for other sources of salt ions to contribute to FSS such as weathering of impervious surfaces, sewage, wastewater, and water softeners (Kaushal et al. 2015, 2017, 2020). We now know that increasing chloride trends and freshwater salinization are impacting freshwaters around the world (Fig. 1). Furthermore, concentrations of multiple ions related to FSS are becoming significantly elevated compared to historical global mean concentrations in freshwaters (Table 1). Thus, FSS explicitly accounts for multiple ions contributing to salinization and diverse impacts. 


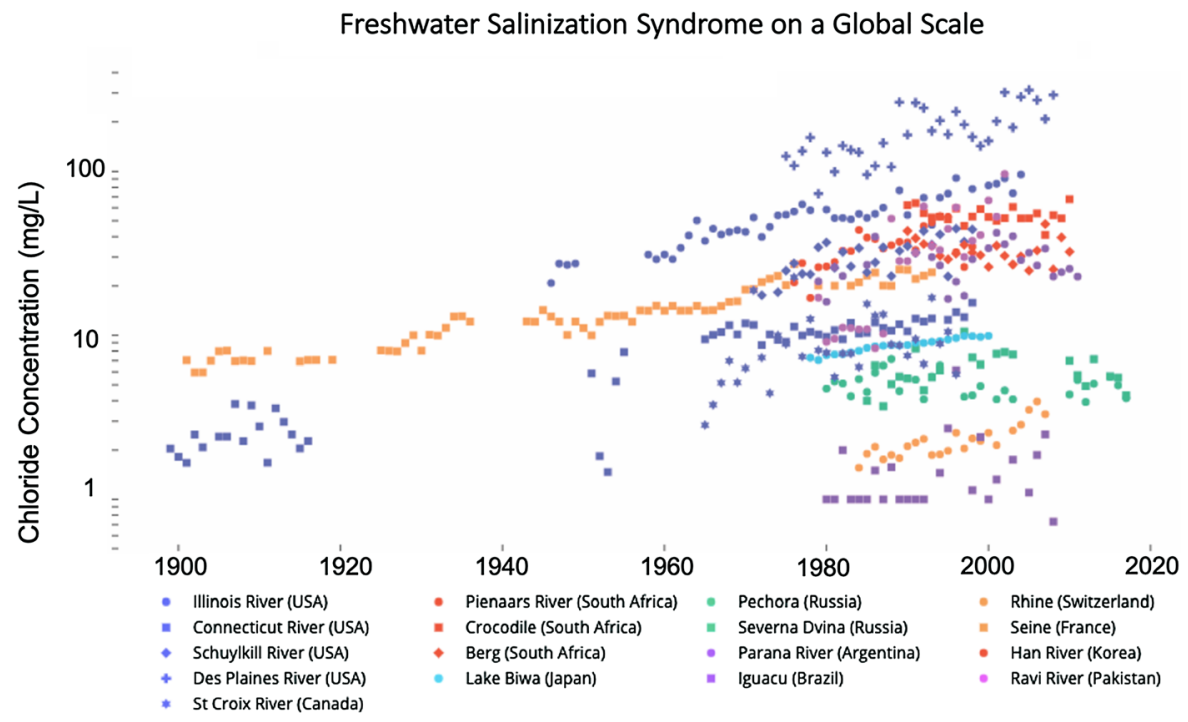

Fig. 1 Increasing $\mathrm{Cl}^{-}$trends in freshwaters globally. Data collected from GEMstat for most rivers. Pienaars River data is from Huizenga et al. (2013). Des Plaines River data is from Kelly et al. (2012). Tuen Mun and Kai Tak data is from
Environmental Protection Department (Environmental Protection Department of HKSAR). Lake Biwa data is from Aota et al. (2003)

Table 1 Summary of common Freshwater Salinization Syndrome (FSS) ions and concentrations

\begin{tabular}{lll}
\hline Common FSS Ions & $\begin{array}{l}\text { Examples of Global Mean } \\
\text { Concentrations }(\mathrm{mg} / \mathrm{L})\end{array}$ & \multicolumn{1}{c}{$\begin{array}{l}\text { Examples of Anthropogenically Enhanced } \\
\text { Concentrations }(\mathrm{mg} / \mathrm{L})\end{array}$} \\
\hline $\mathrm{Na}^{+}$ & $3.66^{[1]}$ & $29.67-32.98^{[2]}$ \\
$\mathrm{Ca}^{2+}$ & $13.48^{[1]}$ & $26.63^{[2]}$ \\
$\mathrm{Mg}^{2+}$ & $3.15^{[1]}$ & $7.31-7.78^{[2]}$ \\
$\mathrm{K}^{+}$ & $1.25^{[1]}$ & $4.14-5.12^{[2]}$ \\
$\mathrm{Cl}^{-}$ & $3.05^{[1]}$ & $0.2-3.8^{[3]}$ \\
$\mathrm{SO}_{4}{ }^{2-}$ & $7.83^{[1]}$ & $1.0-164^{[3]}$ \\
$\mathrm{NO}_{3}{ }^{-}$ & $0.1^{[1]}$ & $1.1-3.92^{[2]}$ \\
$\mathrm{HCO}_{3}{ }^{-}$ & $50.94^{[1]}$ & $27-748^{[3]}$ \\
$\mathrm{Br}^{-}$ & $0.006^{[1]}$ & $0.35-1.05^{[3]}$ \\
$\mathrm{F}^{-}$ & $0.26^{[1]}$ & $0.10-4.02^{[3]}$ \\
$\mathrm{I}^{-}$ & $0.0018^{[1]}$ & $0.0199^{[4]}$ \\
$\mathrm{Mn}^{2+, 7+}$ & $0.034^{[1]}$ & $0.764-7.246^{[5]}$ \\
$\mathrm{Cu}^{1+, 2+}$ & $0.00148^{[6]}$ & $0.00006-1.41^{[7]}$ \\
$\mathrm{Zn}^{2+}$ & $0.0006^{[6]}$ & $0.0007-22.0^{[7]}$ \\
$\mathrm{PO}_{4}{ }^{3-}$ & $0.01^{[8]}$ & $0.01-0.03^{[2]}$ \\
$\mathrm{Sr}^{2+}$ & $0.06^{[6]}$ & $0.169-1.65^{[9]}$ \\
\hline
\end{tabular}

Global mean concentrations from unpolluted rivers are compared to rivers influenced by anthropogenic sources. Concentrations of ions from [1,a] Wetzel 2001: global average chemical compositions and [1,b] Wetzel 2001: approximate average concentration in natural and freshwater, [6] Gaillardet et al. 2003: average composition in surface waters, [8] Meybeck 1982: world averages. Anthropogenically enhanced concentrations include sites with elevated levels of some common Freshwater Salinization Syndrome ions from: [2] Connor et al. 2014, [3] Hellar-Kihampa et al. 2013, [4] Moran et al. 2002, [5] Kshetrimayum and Hegeu 2016, [7] Walker 1999, [9] Le Pape et al. 2012 
Human-accelerated weathering and river

alkalinization contribute to salinization

Human activities can accelerate geological processes such as erosion, chemical weathering rates, acidification-alkalinization, and ion exchange in soils. This provides another justification for expanding our FSS conceptual framework for understanding diverse causes and consequences of salinization in humid regions. During the same time that increases in $\mathrm{Cl}^{-}$ and $\mathrm{Na}^{+}$were being discovered in U.S. freshwaters, positive trends in fluxes of bicarbonate ions and alkalinity were observed in the Mississippi River (Raymond and Cole 2003; Raymond et al. 2008). Agricultural liming was identified as a dominant source of increasing carbonates in agricultural watersheds over the previous century (Raymond and Cole 2003; Raymond et al. 2008). Related work also showed trends in increased chemical weathering products in rivers due to mining activities (Raymond and Oh 2009), a finding also supported by observations of higher specific conductance (an indicator of salinity) in streams of the Appalachian Mountain region due to mining (Palmer et al. 2010; Bernhardt and Palmer 2011). Other work suggested that trends in alkalinity and bicarbonate ions could be partially related to factors such as recovery from acid rain (Stets et al. 2014), although some of these trends began before the Clean Air Act Amendments of 1990, which targeted acid rain (Kaushal et al. 2013, 2018a; Stets et al. 2014). In addition, we found increasing concentrations of base cations in runoff from urbanized watersheds with no or minimal natural carbonate lithology, which suggested other sources such as weathering of impervious surfaces (Kaushal et al. 2014, 2015, 2017; Moore et al. 2017). Dissolved solids in rivers were rising across many regions of the U.S., which was also directly related to freshwater salinization (Anning and Flynn 2014). Interestingly, these trends in dissolved solids also occurred in watersheds not experiencing significant road salt use (Kaushal et al. 2013, 2018a). Our other related work has documented rising river temperatures in some of these same rivers over the past century (Kaushal et al. 2010). Increased temperatures can intensify and spread FSS by evaporative concentration of salt ions, accelerating chemical weathering rates, enhancing toxicity of ions, and contributing to sea level rise and saltwater intrusion (Kaushal et al. 2018a, 2019). Results from our work and others has suggested that there is a growing need to develop a conceptual framework for linking interactive causes and consequences of salinization as a syndrome (Kaushal et al. 2018a, 2019). Further discussion of the role of human-accelerated weathering and other geochemical sources and processes in enhancing diverse causes and consequences of freshwater salinization is given in the section below.

\section{Part 2. Freshwater salinization syndrome: diverse causes and chemical cocktails}

In this section, we begin with a primer on the fundamental geochemistry of freshwater salinization so that readers have the geochemical background to understand the processes referenced later on in the paper in Part 3 (e.g. why many elements desorb with increasing ionic strength and are mobilized by salt ions). We also provide an introduction to the watershed "chemical cocktail" concept (e.g. Kaushal et al. 2018a, b, 2019, 2020; Morel et al. 2020; Galella et al. 2021) and allusions to the emerging toxicological and biogeochemical impacts on ecosystems from complex chemical mixtures.

Fundamental geochemistry of salinizationmaking chemical cocktails

There are important fundamental concepts of geochemistry, which can help explain why many elements desorb and/or are mobilized into solution with increasing salinization and ionic strength. Geochemical processes that enhance elemental mobility with regard to salinization include adsorption changes with ionic strength and $\mathrm{pH}$, and redox effects (sensu Drever 1988; Appelo and Postma 2004); these processes provide more context for the effects of FSS on mobilization of multiple contaminants, which we discuss further in subsequent sections. As just one example, geochemical conditions including $\mathrm{pH}$ and redox determine movement and concentration of trace elements in groundwater. For example, positively charged ions including $\mathrm{Cd}, \mathrm{Co}, \mathrm{Cu}, \mathrm{Pb}, \mathrm{Ni}$, and $\mathrm{Zn}$ sorb onto rocks and sediments at higher $\mathrm{pH}$ because the surface charge of metal oxides and clays becomes more negative, while negatively charged ions such as As, $\mathrm{Cr}, \mathrm{Se}$, and Mo desorb as $\mathrm{pH}$ increases, thereby 
Table 2 A broad synthesis of examples of sources and impacts from common freshwater salinization syndrome ions

\begin{tabular}{|c|c|c|c|c|}
\hline $\begin{array}{l}\text { FSS } \\
\text { Ions }\end{array}$ & $\begin{array}{l}\text { Examples of Geologic and } \\
\text { Atmospheric Sources }\end{array}$ & $\begin{array}{l}\text { Examples of } \\
\text { Anthropogenically } \\
\text { Enhanced Sources }\end{array}$ & $\begin{array}{l}\text { Examples of Diverse } \\
\text { Environmental Implications }\end{array}$ & $\begin{array}{l}\text { Examples of Diverse Health } \\
\text { and Ecotoxicology } \\
\text { Implications }\end{array}$ \\
\hline $\mathrm{Na}^{+}$ & $\begin{array}{l}\text { Weathering of Na-bearing } \\
\text { silicate minerals (e.g. albite) } \\
{[10,11] \text {, atmospheric }} \\
\text { deposition from sea } \\
\text { salts }{ }^{[10,12]} \text {, evaporation and } \\
\text { evaporites }{ }^{[13]}\end{array}$ & $\begin{array}{l}\text { Sewage, fertilizer, road salt }{ }^{[10]} \text {, } \\
\text { drinking water treatment } \\
\text { additives }(e . g . \mathrm{Na} \\
\text { hypochlorite) }\end{array}$ & $\begin{array}{l}\text { Increase algal production, } \\
\text { decrease soil permeability, } \\
\text { aeration, increase overland } \\
\text { flow }^{[15]} \text {, displaces metals, } \\
\text { cations, organic and inorganic } \\
\text { particles in soils }{ }^{[16]}\end{array}$ & $\begin{array}{l}\text { Systolic and diastolic blood } \\
\text { pressure }{ }^{[17]} \text {, Impacts sodium } \\
\text { restricted diets (i.e. treatment } \\
\text { of Miniere's disease), } \\
\text { development of heart disorder } \\
\text { of high risk groups, } \\
\text { hypertension }\end{array}$ \\
\hline $\mathrm{Ca}^{2+}$ & $\begin{array}{l}\text { Weathering of sedimentary } \\
\text { carbonate rocks, rain }{ }^{[10]}\end{array}$ & $\begin{array}{l}\text { Concrete drainage pipes, } \\
\text { weathering of impervious } \\
\text { surfaces } \\
\text { inputs }^{[10]} \text {, atmospheric }\end{array}$ & $\begin{array}{l}\text { Heavy metals ion exchange, } \\
\text { damage to vegetation }\end{array}$ & $\begin{array}{l}\text { Excess } \mathrm{Ca} \text { is secreted by the } \\
\text { kidney (if no renal } \\
\text { impairment), potential issues if } \\
\text { have milk alkali syndrome and } \\
\text { hypercalcemia }{ }^{[20]}\end{array}$ \\
\hline $\mathrm{Mg}^{2+}$ & $\begin{array}{l}\text { Weathering of rocks (e.g. } \\
\text { pyroxenes, dolomites) }\end{array}$ & $\begin{array}{l}\text { Weathering of impervious } \\
\text { surfaces, urban structures }\end{array}$ & $\begin{array}{l}\text { Heavy metals ion exchange, } \\
\text { damage to vegetation }{ }^{[19]}\end{array}$ & $\begin{array}{l}\text { Diarrhea, laxative effect with } \\
\text { high sulfate, hypermagnesemia } \\
\text { (if abnormal kidney } \\
\text { function) }\end{array}$ \\
\hline $\mathrm{K}^{+}$ & $\begin{array}{l}\text { Weathering of silicate minerals } \\
\text { (e.g. K-feldspar, mica, } \\
\text { magnetite) }{ }^{[3,10]} \text { cyclic salt, } \\
\text { decomposition of organic } \\
\text { matter }{ }^{[21]}\end{array}$ & $\begin{array}{l}\text { Concrete drainage pipes }{ }^{[2]}, \\
\text { biomass burning }{ }^{[3]}, \\
\text { agricultural land use, } \\
\text { fertilizers, industrial, } \\
\text { municipal sewage, and } \\
\text { treated water discharge } \\
{[21]}\end{array}$ & $\begin{array}{l}\text { Decrease aquatic organism } \\
\text { growth and reproduction }\end{array}$ & $\begin{array}{l}\text { Unlikely to occur in healthy } \\
\text { individuals, large doses cause } \\
\text { vomiting, hyperkaliemia in } \\
\text { high risk groups }{ }^{[23]}\end{array}$ \\
\hline $\mathrm{Cl}^{-}$ & $\begin{array}{l}\text { Weathering of rocks and } \\
\text { minerals, rainwater from sea } \\
\text { salts }{ }^{[10]} \text {, evaporation } \\
\text { evaporites }^{[13]}\end{array}$ & Air pollution ${ }^{[1]}$ & $\begin{array}{l}\mathrm{More}^{\mathrm{Cl}^{-}} \text {tolerant aquatic } \\
\text { species, lake stratification, } \\
\text { release } \mathrm{Hg} \text { from sediments } \\
\text { acidification, disrupts } \\
\text { microbial processes and } \mathrm{N} \\
\text { cycles, infrastructure } \\
\text { deterioration, corrosion } \\
\text { chlorocomplexation, leaching } \\
\text { of metals in pipes } \\
\text { of6, 27, 28] }\end{array}$ & $\begin{array}{l}\text { Organoleptic issues (Seigel, } \\
\text { 2007); assist in developing } \\
\text { hypertension, risk of stroke, } \\
\text { left ventricular hypertrophy, } \\
\text { osteoporosis, renal stones, } \\
\text { asthma }{ }^{[30]}\end{array}$ \\
\hline $\mathrm{SO}_{4}{ }^{2-}$ & $\begin{array}{l}\text { Weathering of sedimentary } \\
\text { rocks, volcanic activity }{ }^{[10]} \text {, } \\
\text { evaporites (e.g. gypsum) }{ }^{[13]} \text {, } \\
\text { atmospheric deposition }{ }^{[31]}\end{array}$ & $\begin{array}{l}\text { Pollution (fertilizers, wastes, } \\
\text { mining) }{ }^{[10]} \text {, acid rain and } \\
\text { fossil fuel combustion }{ }^{[31,32]}\end{array}$ & $\begin{array}{l}\text { Stimulates microbial sulphate } \\
\text { reduction, increases HS- } \\
\text { concentration, } \\
\text { eutrophication }^{[33]}\end{array}$ & $\begin{array}{l}\text { Catharsis, dehydration, } \\
\text { gastrointestinal irritation }^{[34]}\end{array}$ \\
\hline $\mathrm{NO}_{3}^{-}$ & $\begin{array}{l}\text { Soil nitrification, atmospheric } \\
\text { deposition }^{[35]}, \text { lightning }^{[36]}\end{array}$ & $\begin{array}{l}\text { Agriculture and domestic } \\
\text { practices (e.g. manure), } \\
\text { sewage effluents }{ }^{[35,37]} \text {, fossil } \\
\text { fuels }^{[3]}\end{array}$ & $\begin{array}{l}\text { Acidification, increase primary } \\
\text { producers, cause } \\
\text { eutrophication }{ }^{[3]} \text {, toxic algal } \\
\text { blooms }^{[38]}\end{array}$ & $\begin{array}{l}\text { Methemoglobinemia (Blue Baby } \\
\text { Syndrome), diabetes, } \\
\text { spontaneous abortions, thyroid } \\
\text { problems, certain cancers, } \\
\text { mutagenesis, teratogenesis }{ }^{[38]}\end{array}$ \\
\hline $\mathrm{HCO}_{3}{ }^{-}$ & $\begin{array}{l}\text { Weathering of carbonate } \\
\text { minerals } \\
\text { from biological } \\
\text { respiration }{ }^{[39,40]} \text { autotrophic } \\
\text { respiration, OM } \\
\text { mineralization }{ }^{[40]}\end{array}$ & $\begin{array}{l}\text { Pollution from sewage, } \\
\text { fertilizers, road salt }{ }^{[10]}, \\
\text { concrete drainage pipes }^{[2]}\end{array}$ & $\begin{array}{l}\text { Contributes to the mobility of As } \\
\text { [41], protects from } \\
\text { acidification }{ }^{[42]}, \text { higher } \\
\text { biomass production }{ }^{[43]}\end{array}$ & Metabolic alkalosis $^{[44]}$ \\
\hline $\mathrm{Sr}^{2+}$ & $\begin{array}{l}\text { Sedimentary rocks and calcite } \\
\text { minerals }{ }^{[68]}\end{array}$ & $\begin{array}{l}\text { Nuclear fallout, fertilizers, } \\
\text { industrial manufacturing }\end{array}$ & $\begin{array}{l}\text { Not generally a concern to } \\
\text { aquatic organisms }{ }^{[69]}\end{array}$ & $\begin{array}{l}\text { Abnormal skeletal } \\
\text { developments, bone } \\
\text { calcification, strontium rickets, } \\
\text { (higher impact to infants } \\
\text { because infants have higher } \\
\text { absorption rates into } \\
\text { bloodstream and also higher } \\
\text { rates of bone growth) }\end{array}$ \\
\hline
\end{tabular}


Table 2 continued

\begin{tabular}{|c|c|c|c|c|}
\hline $\begin{array}{l}\text { FSS } \\
\text { Ions }\end{array}$ & $\begin{array}{l}\text { Examples of Geologic and } \\
\text { Atmospheric Sources }\end{array}$ & $\begin{array}{l}\text { Examples of } \\
\text { Anthropogenically } \\
\text { Enhanced Sources }\end{array}$ & $\begin{array}{l}\text { Examples of Diverse } \\
\text { Environmental Implications }\end{array}$ & $\begin{array}{l}\text { Examples of Diverse Health } \\
\text { and Ecotoxicology } \\
\text { Implications }\end{array}$ \\
\hline $\mathrm{F}^{-}$ & $\begin{array}{l}\text { Leaching from fluoride-bearing } \\
\text { minerals (e.g. fluorite, } \\
\text { apatite, mica, amphiboles, } \\
\text { clays, vivianite) in Earth's } \\
\left.\text { crust }^{49,}, 50\right]\end{array}$ & $\begin{array}{l}\text { Added to drinking water }{ }^{[49]} \text {, } \\
\text { mining, pesticides, brick } \\
\text { kilns }^{[51]}\end{array}$ & $\begin{array}{l}\text { Associated with soft, alkaline, } \\
\text { and calcium-deficient water }{ }^{[52]}\end{array}$ & $\begin{array}{l}\text { Dental fluorosis, skeletal, } \\
\text { neurological manifestations, } \\
\text { muscular manifestations, } \\
\text { allergize manifestations, } \\
\text { gastrointestinal problems, head } \\
\text { ache, loss of teeth }{ }^{[49]}, \\
\text { antioxidant defense system, } \\
\text { down syndrome, cytolysis and } \\
\text { phagocyte function, } \\
\text { hematopoiesis, chromosome } \\
\text { exchange and aberration, } \\
\text { neurophysiology and memory } \\
\text { loss, blood biochemistry } \\
\text { alterations }{ }^{[30]}\end{array}$ \\
\hline $\mathrm{I}^{-}$ & $\begin{array}{l}\text { Atmospheric inputs (oceanic } \\
\text { cyclic iodine), weathering, } \\
\text { Iodine volatilization from } \\
\text { plants/organic degradation, } \\
\text { upwelling deep } \\
\text { groundwater }^{[4]}\end{array}$ & $\begin{array}{l}\text { Pesticides, herbicides, } \\
\text { fertilizers, mass production of } \\
\text { crops disposal of oilfield } \\
\text { brines, hospital wastes }^{[4]}\end{array}$ & Impacts aquatic biota $^{[53]}$ & $\begin{array}{l}\text { Goiters, thyroid dysfunction, } \\
\text { hypothyroidism }^{[54]}\end{array}$ \\
\hline $\mathrm{Mn}^{2+, 7+}$ & Weathering of rocks ${ }^{[55]}$ & $\begin{array}{l}\text { Mining, metal smelting, } \\
\text { agriculture }{ }^{[55]}, \\
\text { emissions from steel \& } \\
\text { ferroalloy manufacturing, } \\
\text { wind erosion of soils, additive } \\
\text { in gasoline, coal } \\
\text { combustions }^{[16]}\end{array}$ & Turbidity, deposition in pipes ${ }^{[56]}$ & $\begin{array}{l}\text { Neurotoxin, learning disabilities/ } \\
\text { deficits in intellectual function } \\
\text { in children, Mn-induced } \\
\text { parkinsonism, compulsive } \\
\text { behaviors, emotional lability, } \\
\text { hallucinations, attention } \\
\text { disorders, infant mortality, } \\
\text { cancer }^{[56]} \text {, apathy, irritability, } \\
\text { headache, insomnia, } \text { respiratory diseases }^{[34]}\end{array}$ \\
\hline $\mathrm{Cu}^{1+, 2+}$ & $\begin{array}{l}\text { Copper oxide, copper sulfide, } \\
\text { other ores }{ }^{[58]}\end{array}$ & $\begin{array}{l}\text { Corrosion plumbing, } \\
\text { electroplating wastes, } \\
\text { algicides, pavement wear }^{[7]} \text {, } \\
\text { aquatic plant herbicides, } \\
\text { molluscicides, fungicides, } \\
\text { fertilizers, mining, smelting, }_{\text {burning coal }^{[58]}}\end{array}$ & $\begin{array}{l}\text { Toxicity to freshwater } \\
\text { organisms, growth } \\
\text { inhibition }^{[58]}\end{array}$ & $\begin{array}{l}\text { Diarrhea, abdominal cramps, } \\
\text { nausea, weight gain, vomiting } \\
\text { episodes }{ }^{[54]} \text {, can cause death } \\
\text { by the nervous system, kidney } \\
\text { and liver failure and damage, } \\
\text { chronic anemia, coronary heart } \\
\text { diseases, high blood } \\
\text { pressure }^{[59]}\end{array}$ \\
\hline $\mathrm{Zn}^{2+}$ & $\begin{array}{l}\text { Release and mineralization of } \\
\text { organic detritus }^{[1]}\end{array}$ & $\begin{array}{l}\text { Metal production, waste } \\
\text { incineration, fossil fuels } \\
\text { consumption, phosphate } \\
\text { fertilizers, cement } \\
\text { production, tires and brake } \\
\text { lining }\end{array}$ & Toxic to aquatic biota ${ }^{[61]}$ & $\begin{array}{l}\text { Prostate cancer }{ }^{[62]} \text {, urolithiasis } \\
\text { and urinary tract infection }{ }^{[63]} \text {, } \\
\text { increase testosterone } \\
\text { production, increase } \\
\text { cholesterol, decrease levels of } \\
\text { HDL cholesterol, cause } \\
\text { immune dysfunction }^{[64]}\end{array}$ \\
\hline $\mathrm{PO}_{4}^{3-}$ & $\begin{array}{l}\text { Weathering of sedimentary } \\
\text { rocks (e.g. phosphate bearing } \\
\text { limestone, apatite minerals) } \\
{[10,65] \text {, decomposition of }} \\
\text { organic matter }{ }^{[66]}\end{array}$ & $\begin{array}{l}\text { Inorganic fertilizers, farm } \\
\text { manure, animal waste }{ }^{[3]}\end{array}$ & $\begin{array}{l}\text { Accelerates plant growth, algal } \\
\text { blooms, eutrophication, } \\
\text { decrease water transparency }\end{array}$ & $\begin{array}{l}\text { Not considered a direct toxin to } \\
\text { humans, but does cause toxic } \\
\text { algal blooms or anoxic } \\
\text { conditions that can be } \\
\text { harmful }^{[67]}\end{array}$ \\
\hline
\end{tabular}


Table 2 continued

\begin{tabular}{|c|c|c|c|c|}
\hline $\begin{array}{l}\text { FSS } \\
\text { Ions }\end{array}$ & $\begin{array}{l}\text { Examples of Geologic and } \\
\text { Atmospheric Sources }\end{array}$ & $\begin{array}{l}\text { Examples of } \\
\text { Anthropogenically } \\
\text { Enhanced Sources }\end{array}$ & $\begin{array}{l}\text { Examples of Diverse } \\
\text { Environmental Implications }\end{array}$ & $\begin{array}{l}\text { Examples of Diverse Health } \\
\text { and Ecotoxicology } \\
\text { Implications }\end{array}$ \\
\hline $\mathrm{Br}^{-}$ & $\begin{array}{l}\text { Dissolution of evaporitic rocks, } \\
\text { meteoric recharge }{ }^{[45]} \text {, marine } \\
\text { aerosols, throughfull and } \\
\text { stemflow } \\
\text { intrusions }^{[46]} \text {, saltwater }\end{array}$ & $\begin{array}{l}\text { Sewage }{ }^{[37]} \text {, oil and gas } \\
\text { wastewater, coal-fired power } \\
\text { plants, flame retardant textile } \\
\text { production facilities }^{[47]}\end{array}$ & $\begin{array}{l}\text { Impaired reproduction in } \\
\text { crustacean and fish }\end{array}$ & $\begin{array}{l}\text { Corrosive to human tissues as a } \\
\text { liquid, vapors irritate eyes and } \\
\text { throat, damage nervous } \\
\text { system, thyroid glands }{ }^{[37]}, \\
\text { Higher production of } \\
\text { brominated disinfection } \\
\text { byproducts after drinking } \\
\text { water disinfection, more } \\
\text { carcinogenic than chlorinated } \\
\text { analogues }^{[45]}\end{array}$ \\
\hline
\end{tabular}

Geologic and atmospheric sources are natural sources from: ([1] Wetzel 2001, [3] Hellar-Kihampa et al. 2013, [4] Moran et al. 2002, [10] Allen 1985, [11] Subramani et al. 2010, [12] Farrell 1995, [13] Apaydın and Aktaş 2012, [21] Talling 2010, [24] Krumgalz et al. 2002, [31] González and Aristizábal 2012, [35] Mayer et al. 2002, [36] Tost 2017, [39] Singh et al. 2008, [40] Campeau et al. 2017, [45] D'Alessandro et al. 2008, [46] Neal et al. 2007, [47] Good and VanBriesen 2016, [49] Rao 2003, [50] Li et al. 2014a, b, [55] Li et al. 2014a, b, [58] de Oliveira-Filho et al. 2004, [65] Manning 2015, [66] Meyer 1980, [68] Scott et al. 2020)

Examples of anthropogenically enhanced sources are from: ([1] Wetzel 2001, [2] Connor et al. 2014, [3] Hellar-Kihampa et al. 2013, [4] Moran et al. 2002, [7] Walker 1999, [10] Allen 1985, [14] Lantagne 2008, [16] Herndon et al. 2011, [21] Talling 2010, [31] González and Aristizábal 2012, [32] Menz and Seip 2004, [35] Mayer et al. 2002, [37] Ghadimi et al. 2016, [47] Good and VanBriesen 2016, [49] Rao, [51] Ali et al. 2016, [55] Li et al. 2014a, [58] de Oliveira-Filho et al. 2004, [60] Councell et al. 2004, [68] Scott et al. 2020)

Examples of potential environmental impacts are from: ([3] Hellar-Kihampa et al. 2013, [15] Ramakrishna and Viraraghavan 2005, [16] Herndon et al. 2011, [19] Fay and Shi 2012, [22] Skowron et al. 2018, [25] Gene E. Likens 2009, [26] Pieper et al. 2018, [27] Acosta et al. 2011, [28] Zhao et al. 2013, [33] Cañedo-Argüelles et al. 2013b, [38] Qasemi et al. 2018, [41] L. DeVore et al. 2019, [42] Maul et al. 2014, [43] Mokashi et al. 2016, [48] Canton et al. 1983, [52] Ozsvath 2009, [53] Tiffany et al. 1969, [56] Tobiason et al. 2016, [58] de Oliveira-Filho et al. 2004, [61] Gozzard et al. 2011, [69] McPherson et al. 2014)

Examples of potential health and ecotoxicology impacts are from: ([17] Khan et al. 2011, [18] Calabrese and Tuthill 1977, [20] World Health Organization 2011, [23] World Health Organization 2010, [30] Vinod K. Garg et al. 2009, [34] Virkutyte and Sillanpää 2006, [37] Ghadimi et al. 2016, [38] Qasemi et al. 2018, [44] Siener et al. 2004, [45] D'Alessandro et al. 2008, [49] Rao 2003, [54] Knobeloch et al. 1994., [56] Tobiason et al. 2016, [59] Mohod and Dhote 2013, [62] Leitzmann et al. 2003, [63] Johnson et al. 2007, [64] Moyad 2004, [67] Carpenter et al. 1998, [68] Scott et al. 2020)

effecting higher groundwater concentrations (DeSimone et al. 2014). As another example, lead can also move quickly into groundwater when organic matter and soil $\mathrm{pH}$ are low (Walraven et al. 2014). Thus, there are multiple complex interactions between ionic strength and $\mathrm{pH}$, redox, organic matter, and other chemical parameters, which can enhance FSS mobilization of complex mixtures of multiple contaminants or chemical cocktails. Cocktail effects have been a useful concept in toxicology, but we expand our concept of chemical cocktails to include not only impacts on health and ecosystems, but also sources, fate, and transport of complex chemical mixtures in the environment (Kaushal et al. 2018a, 2019, 2020; Morel et al. 2020; Galella et al. 2021).

Typically, chemical cocktails mobilized by FSS can be from either geologic or anthropogenically enhanced sources and have diverse environmental and health impacts (Table 2). In extensive surveys nationwide by the U.S. Geological Survey (USGS), 22\% of groundwater wells sampled had at least one contaminant; 5\% from anthropogenic and $17 \%$ from geologic sources, including $78 \%$ of the samples that exceeded a human health benchmark (DeSimone et al. 2014). Old groundwater is more likely to have geologic contaminant sources such as Mn, As, Rn, Sr, U, F, Mo, Pb, Sb, $\mathrm{Se}, \mathrm{Zn}$ than newer groundwater because of the longer time for reaction with minerals and prevalence of anoxic conditions while $\mathrm{NO}_{3}{ }^{-}$is the most common anthropogenic groundwater contaminant from fertilizers, fossil fuel combustion, and human and animal wastes (DeSimone et al. 2014). Reducing conditions often drive $\mathrm{NO}_{3}{ }^{-}$transformations when groundwater becomes anoxic and reduction of $\mathrm{NO}_{3}{ }^{-}$is paired with oxidation of other chemicals, usually organic carbon which becomes an electron donor and oxygen 
becomes the electron acceptor (i.e. order of electron acceptors is $\mathrm{O}_{2}, \mathrm{NO}_{3}{ }^{-}, \mathrm{Mn}, \mathrm{Fe}, \mathrm{SO}_{4}{ }^{-2}$ and $\mathrm{CO}_{2}$ ). There are many other examples of biological, geological, and chemical processes leading to couplings and pairings of elemental cycles in the environment and formation of complex chemical cocktails in freshwaters; FSS enhances and intensifies many of these geochemical and biogeochemical processes, which leads to co-mobilization of multiple contaminants and chemical cocktails in ground and surface waters (e.g. Kaushal et al. 2018a, b, 2019, 2020; Morel et al. 2020; Galella et al. 2021).

FSS chemical cocktails are emerging forms of nonpoint source pollution

The FSS can be attributed to diverse nonpoint sources of salt ions such as: (1) direct anthropogenic salt inputs; (2) human-accelerated weathering of infrastructure, rocks, and soils; (3) increased sea level rise and saltwater incursion; (4) evaporative concentration of salt ions from hydrologic modifications and climate; and (5) disturbance of vegetation and local groundwater hydrology. In addition to the geochemical processes above, these multiple sources and origins of FSS can also lead to the formation of novel and complex ionic mixtures, or chemical cocktails (Kaushal et al. 2018a, 2019, 2020). The diverse nonpoint sources also indicate the need for innovative management to reduce salt inputs to freshwater ecosystems. Nonpoint sources include road salts, sewage leaks and discharges, discharges from water softeners, agricultural fertilizers, fracking brines enriched with major ions, and septic systems (Kaushal et al. 2018a). Road salt is typically comprised of $\mathrm{Na}^{+}$ and $\mathrm{Cl}^{-}$ions (Dugan et al. 2017), but also can include $\mathrm{Ca}^{2+}, \mathrm{Mg}^{2+}$, and acetate depending on applications. Sewage can be enriched in $\mathrm{Na}^{+}, \mathrm{K}^{+}, \mathrm{Mg}^{2+}, \mathrm{Ca}^{2+}$, and $\mathrm{Cl}^{-}$and all major ions from human diets whereas home water softeners typically discharge $\mathrm{Na}^{+}, \mathrm{K}^{+}$, and $\mathrm{Cl}^{-}$. Many household products contain major ions and $\mathrm{Na}^{+}$and other salt ions are also added during the water treatment process (Bhide et al. 2020). Fracking produces brines with elevated salinity, alkalinity, and total dissolved solids, which are enriched in $\mathrm{Br}^{-}, \mathrm{I}^{-}$, $\mathrm{Cl}^{-}$, and $\mathrm{NH}_{4}^{+}$and other ions (Vengosh et al. 2017). Agricultural fertilizers contain $\mathrm{NO}_{3}{ }^{-}, \mathrm{NH}_{4}{ }^{+}, \mathrm{H}_{2} \mathrm{PO}_{4}{ }^{-}$, $\mathrm{HPO}_{4}{ }^{-}, \mathrm{Mg}^{2+}, \mathrm{K}^{+}, \mathrm{Ca}^{2+}$, and $\mathrm{SO}_{4}{ }^{2-}$ as macronutrients and $\mathrm{Cl}^{-}$as a micronutrient (Schlesinger 2020).
In addition, there can be human-accelerated weathering in agricultural and urban watersheds, which contribute to diverse causes and consequences of FSS. For example, highly urbanized settings often contain structures built from limestone, concrete, gypsum, and other materials, which release major ions when weathered. During construction, materials from bedrock are released by weathering, soils are exposed to erosion and weathering, and more ions are mobilized into the surrounding environment. In fact, many constructed drainage systems in urbanized areas can be rich in carbonates and other major ions. The release of these ions due to weathering contributes to a distinct urban lithology known as the "urban karst" (e.g. Kaushal and Belt 2012; Kaushal et al. 2014, 2015, 2017, 2020). Ammonium-based fertilizers, which enhance nitrification and soil acidification, also accelerate the weathering of minerals, soils, and mobilization of major ions in urban lawns and agricultural fields. Further, $\mathrm{SO}_{4}{ }^{2-}$ applied as pesticide and fertilizers to agricultural fields can immobilize $\mathrm{Fe}$ and release $\mathrm{P}$ from aquatic sediments (Hinckley et al. 2020). Thus, human-accelerated weathering of the built environment, fertilized agricultural lands, mined lands, and even minimally disturbed forests and other lands can all potentially mobilize $\mathrm{Ca}^{2+}, \mathrm{K}^{+}, \mathrm{Mg}^{2+}$, $\mathrm{SO}_{4}{ }^{2-}$, carbonates, and other ions contributing to FSS.

FSS chemical cocktails impact ecosystems directly and indirectly

Mobilization of major ions, metals, and nutrients into chemical cocktails can affect biodiversity and ecosystem processes (Cañedo-Argüelles et al. 2013a, b; Schuler and Relyea 2018; Iglesias 2020). As concentrations of nutrients have been regulated and monitored for the protection of aquatic life and safe drinking water (e.g. Total Maximum Daily Loads or TMDL's in the Chesapeake Bay watershed and elsewhere), specific conductance from salinization has increased due to lack of corresponding regulations for salt ions (Fig. 2). This has led to increasing specific conductance in rivers across all seasons due to accumulation of salt ions in soils and groundwater (Fig. 2), as mentioned above. However, ecosystem impacts of FSS as seasonal ion pulses or chronically elevated ion concentrations throughout the year are still poorly understood and may vary across watersheds due to state factors such as climate, topography, 
underlying geology, biota, and time (Kaushal et al. 2019, 2020). Chemical cocktails can result in the depletion or reduction of native and sensitive species including fish, macroinvertebrates, and plants (Cañedo-Argüelles et al. 2013a, 2016b; Schuler and Relyea 2018; Iglesias 2020), and may increase the

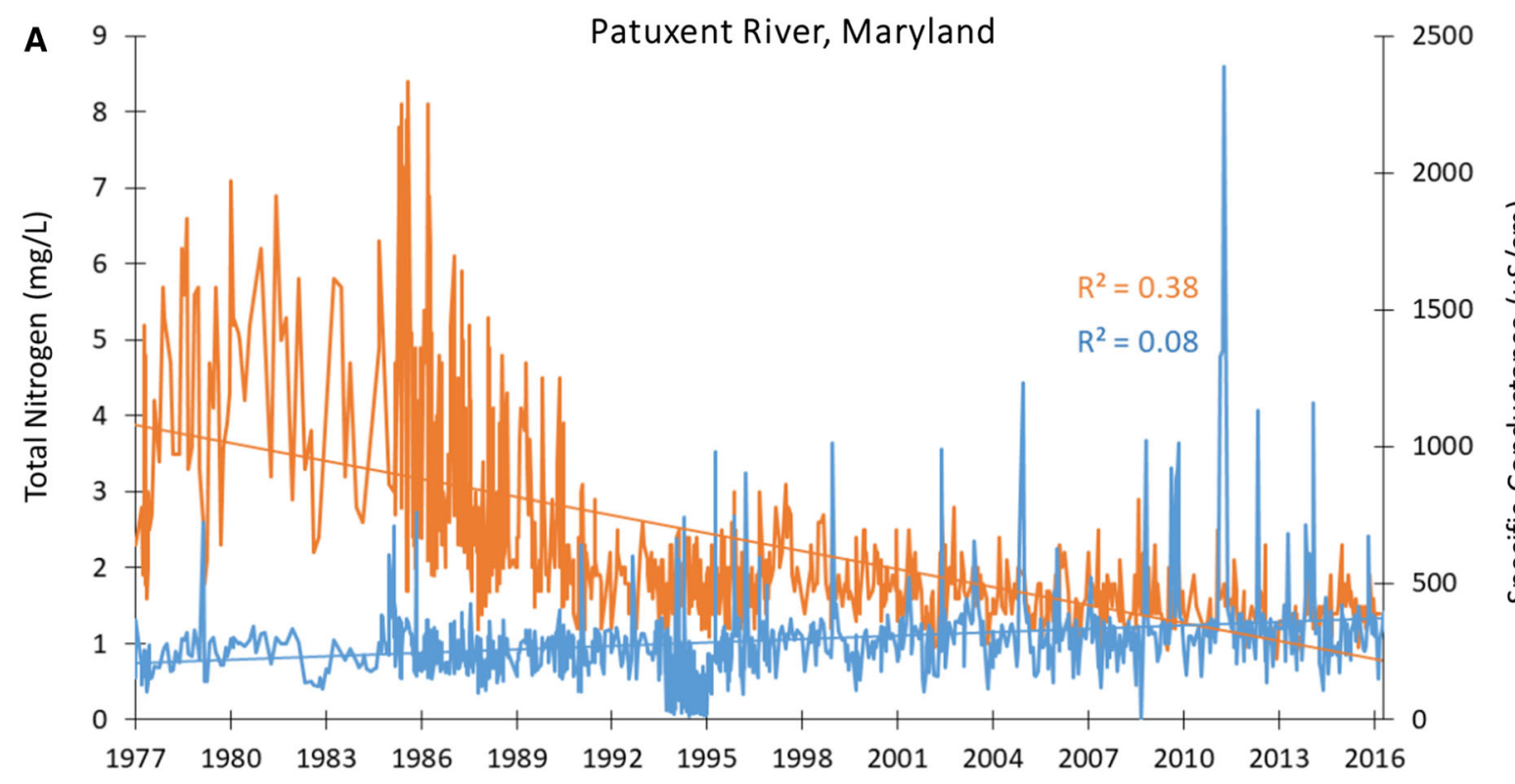

-Total Nitrogen - Specific Conductance

Passaic River, New Jersey

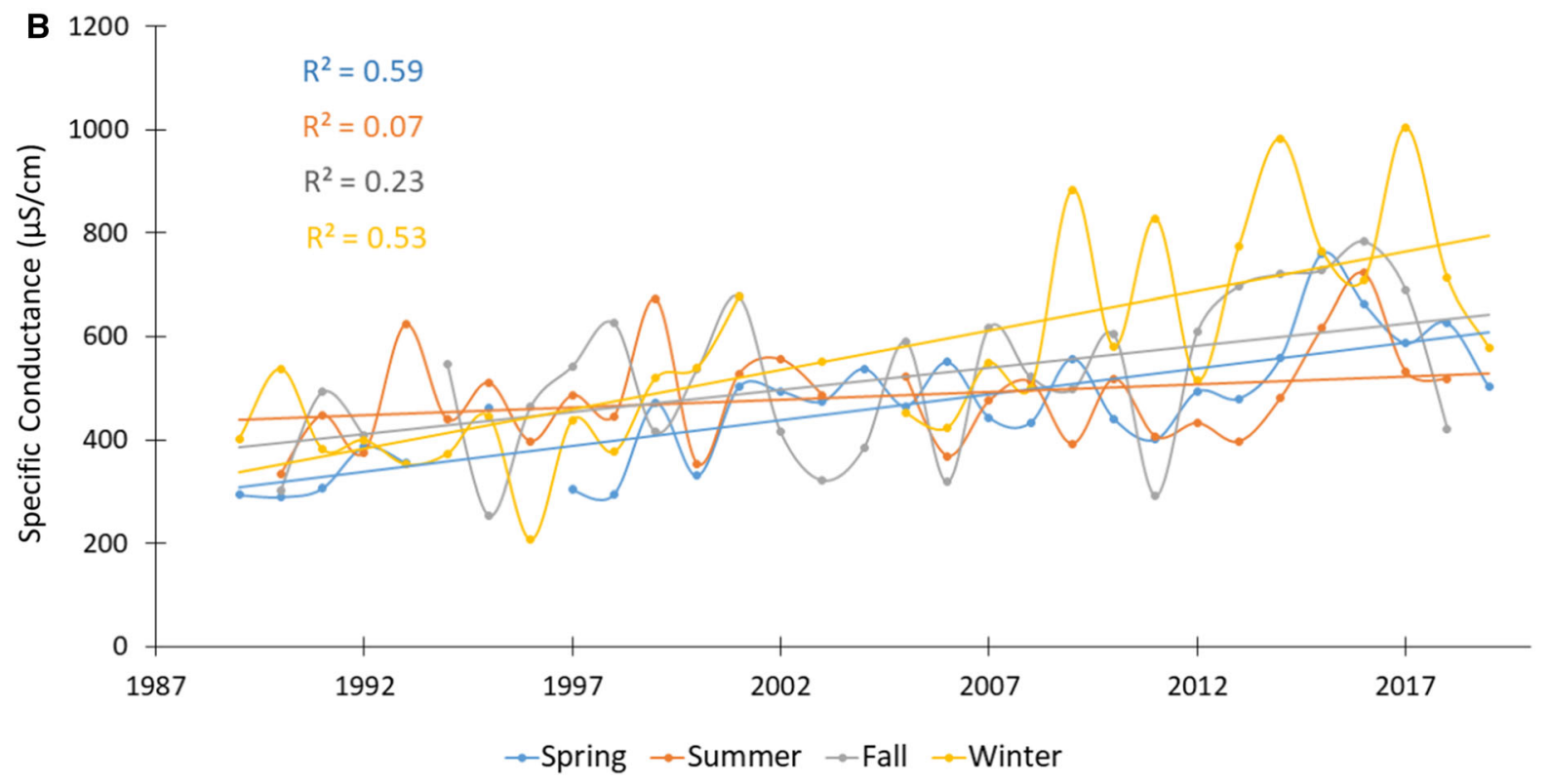

Fig. 2 Decreasing trends in nitrogen concentrations in the Patuxent River in Bowie, Maryland, USA, (USGS gage $01,594,440$ ) over years due to nutrient regulations in the Chesapeake Bay watershed and increasing trends in specific conductance (Top Panel). Increasing specific conductance over years across all seasons indicated by seasonal yearly means in the Passaic River, New Jersey, USA (USGS gage 01,389,005) (Bottom Panel) 
potential for salt-tolerant invasive species to proliferate in these aquatic systems, thereby contributing to ecosystem impacts. Organisms that are more sensitive to shifts in water salinity are likely to exhibit greater mortality rates. For example, chemical cocktails of metals and major ions can reduce the species richness of mayflies (Ephemeroptera), caddisflies (Trichoptera), stoneflies (Plecoptera), and chironomids (Diptera) (Schuler and Relyea 2018). Increased anthropogenic salinization, due to elevated $\mathrm{Ca}^{2+}$, $\mathrm{HCO}_{3}{ }^{-}, \mathrm{SO}_{4}{ }^{2-}$, and $\mathrm{Mg}^{2+}$, can influence ecosystem structure and function through losses of sensitive aquatic taxa. The FSS induces trophic cascades and may influence biomagnification of contaminants through food webs (Van Meter et al. 2011; CañedoArgüelles et al. 2016b; Hintz et al. 2017). There are also potential consequences of continued heavy-metal contamination on microbial and biogeochemical processes in streams contributing to cascading effects that reduce ecosystem function and ecosystem services (Schuler and Relyea 2018). Metals mobilized by salt ions can reduce plant litter decomposition in aquatic ecosystems and alter microbial respiration (Duarte et al. 2008; Ferreira et al. 2016). It is difficult to comprehensively predict how FSS affects autotrophic and heterotrophic metabolic activities without further ecosystem scale studies and manipulation experiments and this topic represents a new research frontier.

\section{Part 3. Freshwater salinization syndrome: critical research areas and identifying risks}

Based upon almost 20 years of investigating FSS, we review and prioritize the following areas of critical research identifying risks from diverse causes and consequences. Specifically, we review and highlight the need for investigating approaches for better identifying and quantifying FSS sources, FSS causes and consequences and emerging risks from diverse FSS chemical cocktails (e.g. Table 2).

Identifying the expanding role of saltwater intrusion in FSS

Saltwater intrusion has been documented for over 150 years in the US, and contributes significantly to FSS elsewhere (Barlow and Reichard 2010). Coastal communities often use groundwater as their primary source of drinking water (and primary source of domestic and commercial water), but over-pumping of fresh groundwater near saline groundwater contributes to saltwater intrusion (Paul et al. 2019). Sea level rise resulting from global warming and thermal expansion of water and post-glacial rebound can increase saltwater intrusion and affect the amount of freshwater available for coastal communities. Historically, there is evidence of higher sea levels increasing the amount of saltwater intrusion and the salinization of aquifers. In some areas along the U.S. East Coast, there are large aquifers of residual seawater that collected when sea levels were higher in the Pleistocene (Sprinkle 1989). When sea levels receded over the past 900,000 years, freshwater recharge created confined freshwater aquifers offshore of the Atlantic coast of the USA (Meisler 1989). Large-scale sea level changes affect the thickness of transition zones between fresh and salt waters. Repeated advance and retreat of sea level leads to thicker transition zones and, as a result, a greater volume of brackish water that can intrude into freshwater aquifers (Meisler 1989; Barlow and Reichard 2010). Because saltwater intrusion is often caused by relative sea-level rise or hydrologic alterations often as a result of human activities (Paul et al. 2019), and because natural saltwater varies in ionic composition and differs from salinized freshwater sources (Feistel et al. 2015), the role of saltwater intrusion requires special consideration in addressing FSS.

Saltwater intrusion related to relative sea-level rise is accompanied by increasing inundation of soils. This inundation leads to physical disturbance of soils by flowing water and mixing (Ferronato et al. 2019) and bioturbating organisms like marine worms (Valdemarsen et al. 2018), resulting in the dispersion of soil aggregates and movement of sediment, and the increasing availability of elements once sequestered within those aggregates. Aggregate dispersion is further exacerbated by several processes including microbial reduction of cementing oxide minerals (e.g. $\mathrm{Fe}, \mathrm{Mn}$ oxide "glues") (Weissman and Tully 2020; Krause et al. 2020) and dispersion of clay minerals by salt ions (Abbaslou et al. 2020). This results in a release of soluble ions including $\mathrm{Fe}, \mathrm{Mn}$, and compounds associated with their oxides, in addition to nutrients $($ e.g. $\mathrm{P}, \mathrm{N})$ released by cation exchange with seawater, particularly in nutrient-rich agricultural settings (Tully et al. 2019b; Weissman and Tully 2020). At the same time, reductive processes tend to 
immobilize some elements including $\mathrm{Cr}$ (Tokunaga et al. 2001). So, saltwater intrusion of soils represents a complex set of environmental tradeoffs that will vary by setting and create chemical cocktails that differ from both the intruding seawater and the intruded porewater.

The relationships among salt ions and clay minerals are not completely understood, particularly within the context of saltwater intrusion. Some ions cause some clays to disperse, while others cause them to flocculate (Goldberg and Forster 1990). Although clay dispersion is commonly thought to occur in saltwater, intact clay films can be found in upland soils that have been submerged by estuarine water for centuries. Research is needed to understand better how different soils and geologic materials will behave as they are impacted by saltwater intrusion. There may be conditions where saltwater intrusion causes clay dispersion to plug pores, offering aquifers some protection from further saltwater intrusion. There may also be conditions where saltwater intrusion raises the $\mathrm{pH}$ and provides base cations for the formation of minerals such as smectites (Reid-Soukup and Ulery 2018), removing ions from solution as a new mineral-porewater equilibrium is established.

Mineral-porewater interactions under saltwater intrusion scenarios can also impact the atmosphere. Sulfate, supplied by seawater, significantly decreases rates of $\mathrm{CH}_{4}$ production under anoxic conditions as sulfate is preferentially reduced by microbes (Helton et al. 2014; Wen et al. 2019). Sulfate reduction creates $\mathrm{H}_{2} \mathrm{~S}$, which bonds with $\mathrm{Fe}$ to create $\mathrm{FeS}$ minerals (Wessel and Rabenhorst 2017). In environments with enough $\mathrm{Fe}$, an "iron curtain" captures most of the $\mathrm{H}_{2} \mathrm{~S}$ created (Schoepfer et al. 2014). However, in environments without enough $\mathrm{Fe}$ to capture $\mathrm{H}_{2} \mathrm{~S}, \mathrm{H}_{2} \mathrm{~S}$ can be released to the water column or atmosphere, causing fish kills and foul odors (Schunck et al. 2013). Better prediction of changes in the fluxes of $\mathrm{CH}_{4}, \mathrm{H}_{2} \mathrm{~S}$, and other gases as saltwater intrusion occurs is vital for environmental management.

Saltwater intrusion also alters organic matter dynamics and chemical cocktails. Saltwater intrusion reduces dissolved organic carbon (DOC) export from coastal freshwater wetlands through various mechanisms including reduced primary productivity and DOC flocculation (Ardón et al. 2016). Low-elevation coastal forests stressed by saltwater intrusion may be replaced by other vegetative communities, compromising the ability of these landscapes to sequester carbon (Ury et al. 2020). Ghost forests line the salty edges of impacted wetlands, full of dead trees that are slowly releasing the carbon they once sequestered (Kirwan and Gedan 2019). Reportedly, more carbon is sequestered by migrating salt marshes than is lost as forests die back (Hussein et al. 2004). However, as marshes are lost to relative sea-level rise (or if they cannot migrate into ghost forests), the fate of this carbon remains closely tied to interactions with chemical cocktails, which remain poorly understood.

Identifying direct and indirect effects of FSS on groundwater resources

About half of the world's population relies on groundwater for drinking water (Zekster and Everett 2004) including almost half of the U.S. population relying on groundwater for domestic purposes including drinking water (DeSimone et al. 2014; Dieter et al. 2018). Locally, this percentage can be much higher. Because groundwater is often consumed for drinking water, contaminants in groundwater pose health risks. Salinization can increase the risk of contamination from a wide suite of metal and radionuclide copollutants including $\mathrm{As}, \mathrm{Cd}, \mathrm{Cr}, \mathrm{Cu}, \mathrm{Fe}, \mathrm{Hg}, \mathrm{Ni}, \mathrm{Pb}$, $\mathrm{Ra}, \mathrm{U}, \mathrm{Zn}$, and alpha and beta radioactive particles (Schuler and Relyea 2018; Lazur et al. 2020). Heavy metals and radionuclides cause multiple health issues (USEPA 2002, 2009). For example, in areas of the northern USA, people depend on groundwater from glacial aquifers for drinking water, and there are already health implications to about 4 million people from high concentrations of $\mathrm{Mn}$ and $\mathrm{As}, \mathrm{NO}_{3}{ }^{-}$, volatile organic compounds, and pesticides (Erickson et al. 2019). The U.S. Environmental Protection Agency (USEPA) advises a level for $\mathrm{Na}^{+}$in drinking water of $20 \mathrm{mg} / \mathrm{L}$ and a total daily intake of $500 \mathrm{mg}$ /day (USEPA 2003). Therefore, drinking water with high salt levels is a health risk and some US municipalities have reported exceedances of $\mathrm{Cl}^{-}$ above the USEPA secondary-drinking-water threshold of $250 \mathrm{mg} / \mathrm{L}$ (Corsi et al. 2010). However, it is important to mention that currently there are only secondary maximum contaminant levels for chloride; the USEPA also does not currently enforce these levels. These guidelines are to assist public water systems in managing their drinking water for aesthetic considerations, such as taste, color, and odor. 
Although chloride and FSS chemical cocktails have not been previously considered to present a risk to human health in the past, our comprehensive review suggests that chloride and FSS chemical cocktails warrant further and deeper consideration for primary water quality criteria. High dependence on groundwater for drinking water also creates an even greater concomitant risk from consuming water contaminated with mobilized co-pollutants exacerbated by FSS from either geologic or anthropogenically enhanced sources (Stets et al. 2018; Lazur et al. 2020).

Movement of groundwater contaminants is controlled by hydrologic flowpaths. For example, contaminants move to deeper aquifers when groundwater flow is altered during withdrawals for water supply and irrigation. Because arsenic, for example, is found in high concentrations where surrounding minerals are derived from volcanic and crystalline rock (DeSimone et al. 2014) creating regional "hotspots" of groundwater As. There are also comparably high concentrations of arsenic found in aquifers in Holocene alluvial/ deltaic sediments from Vietnam and Bangladesh (Smedley and Kinniburgh 2002). Nonetheless, vertical gradients of elements are important patterns observed naturally in aquifers. However, these patterns can be altered by pumping and withdrawal for agriculture leading to salinization. In the High Plains aquifer underlying the Great Plains of the USA, vertical gradients of dissolved solids (including salt ions) have been changed and even reversed when brackish water from deeper layers moves up and where irrigation recharge elevates concentrations nearer to the surface (DeSimone et al. 2014). The high plains is semiarid, but there are other examples in humid regions from North Carolina and Florida in the USA and Japan (Yamanaka and Kumagai 2006; Vinson et al. 2011; Maslia and Prowell 1990). Contaminants such as salt ions often move in plumes through groundwater, especially when emanating from point sources such as underground tanks or mine sites, following flowpaths of greatest porosity and preferential flow. Characterizing these hydrologic flowpaths can involve installing extensive networks of groundwater wells to monitor movement. In general, researchers typically don't have access to the same kind of high-quality monitoring records for groundwater that are available for surface water. This makes it even more difficult to identify, quantify, and manage salinization trends (which aren't related to saltwater intrusion or a chemical spill event). However, research on trends in groundwater quality is steadily growing (Burow et al. 2017).

Identifying risks of FSS on groundwater quality from resource extraction

Groundwater quality can also be degraded by petroleum drilling operations, where improperly sealed wells leak hydrocarbon contaminants into groundwater and/or from improper disposal of the mass amounts of saline water produced coincidentally with oil extraction (Kharak et al. 2013; Jackson et al. 2014). These brines can be extremely saline ( $>200,000 \mathrm{mg} / \mathrm{L}$ TDS) and contain metals and naturally occurring radioactive elements including ${ }^{226} \mathrm{Ra}$, ${ }^{228} \mathrm{Ra}$ and ${ }^{222} \mathrm{Rn}$, and have led to contamination of groundwater in the US (Kharaka and Otton 2007). The salinity of produced water varies greatly depending on basin. For example, produced water from California, USA tends to be much less saline than from the Marcellus shale region of the USA (Kondash et al. 2020). Groundwater wells in residential homes in the Marcellus shale region of Pennsylvania, USA showed effects of unconventional energy extraction (hydraulic fracturing) including increased salts, metals and radioactivity thought to be primarily due to well casing integrity problems (Osborn et al. 2011; Jackson et al. 2013). Benzene and solvents common in hydraulic fracturing fluids were found in groundwater in Wyoming, USA (DiGiulio et al. 2011) and high levels of As, Se, Sr, and TDS were found in drinking water wells in proximity to fracking activity (Fontenot et al. 2013). As groundwater is progressively depleted globally, deeper saline water reserves are increasingly being explored as drinking water sources. Because these reserves are often closer to the formations where petroleum and natural extractions gas occurs, including zones for wastewater injection, more of these reserves are at risk of contamination (Kang and Jackson 2016). Previous work has linked resource extraction with formation of brines and increased salinization thus contributing to FSS (Palmer et al. 2010; Vengosh et al. 2017). More work is necessary to examine the extent of FSS induced by resource extraction and groundwater reserves and resources at risk. In addition to groundwater, it is important to note that surface waters are also at risk from FSS from oil 
and gas extraction and other forms of resource extraction.

Identifying risks of FSS on human health risks and safe drinking water

The FSS and associated chemical cocktails may pose a risk to human health. For example, it is known that specific chemical contaminants can contribute to skin, vascular, nervous system disorders, and cancer. However, it is not currently known if, how, and when FSS can impact transport and toxicity of these and other chemical contaminants in the environment. Those potential risks can be prevented by establishing and adhering to drinking water standards that also account for potential FSS mobilization of contaminants and chemical cocktails (Foster et al. 2019). However, such standards do not take into consideration mixtures of elements that form chemical cocktails that, together, may have synergistic, or negative effects. For example, groundwater salinization and high concentrations of $\mathrm{Cl}^{-}$, specific conductance, and dissolved solids coupled with low $\mathrm{pH}$ was found to increase risk from trace metals (Fe, Mn, As, B, Pb) in Bangaladesh (Rakib et al. 2020). It may be important to clarify that salinization and these factors increase the extent of contaminant co-occurrence, not the health effects themselves, which were not evaluated in this study. In addition, up to 220 million people globally are at risk of exposure to elevated levels of As in groundwater, which can also be mobilized by saltwater intrusion (LeMonte et al. 2017), primarily in Asia where As is released under anoxic conditions from reduction of arsenic-bearing iron III minerals in areas of recently deposited alluvial sediment (Podgorski and Berg 2020). Risk of exposure to co-occurring, multiple heavy metals (chemical cocktails) in drinking water are pervasive in developing countries where drinking water alternatives are not available, and standards do not exist (Chowdhury et al. 2016). Coastal residents are especially at risk from saline water intrusion that often is exacerbated by anthropogenic activities and water use. For example, in a coastal area of China, groundwater salinization increased the mobility of As, $\mathrm{Co}, \mathrm{Cr}, \mathrm{Cu}, \mathrm{Fe}, \mathrm{Mn}$, and $\mathrm{Ni}$ in an area with high concentrations of total dissolved solids (TDS), significantly increasing cancer risk, especially for children (Wen et al. 2019). While salt ions can exacerbate contaminant mobility, salinity alone in drinking water can increase health costs and these risks could be exacerbated by increasing sea level rise causing more salt water intrusion along coasts (refer to above) (Khan et al. 2011; Vineis et al. 2011).

Although we have previously discussed examples from saltwater intrusion, other forms of salinization also typically lead to violations of multiple drinking water standards such as mining, agriculture, and urbanization. Exposure to saline drinking water and co-pollutants increases overall health care costs, emphasizing the importance of establishing water quality standards (i.e. USEPA currently has aquatic life criteria for chloride and secondary values or advisories for sodium, but USEPA does not currently have national primary drinking water regulations for these salt ions) and providing infrastructure for safe drinking water, especially in developing countries (Das et al. 2019). Sodium concentrations are increasing throughout hundreds of kilometers of the Potomac River, a major drinking water source and supply for Washington, D.C., USA and other nearby cities due to increasing urbanization and pollution (Fig. 3). Specific conductance near the drinking water intake for Washington, D.C. is strongly related to multiple ions and organic matter in drinking water (Fig. 3). Specific conductance may serve as a proxy for predicting concentrations of ions (discussed later), and indicate diverse chemical cocktails that impact infrastructure and human health. Major ion concentrations in the Washington D.C. water supply are still relatively low compared to some regions, but there is evidence to suggest that this relatively fresh water could still mobilize manganese and other metals and have implications for human health (Shaver 2015). There are many diverse sources and health impacts of chemical cocktails related to FSS, which require further investigation (Table 2).

Identifying FSS impacts on plumbing, pipe corrosion, and drinking water

Drinking water risks from high concentrations of salts and co-occurring metals are also both direct and indirect in the form of damage to drinking water infrastructure. One of the most well-documented cases of $\mathrm{Pb}$ contamination related to pipe corrosion from chloride occurred in Flint, Michigan, USA; it primarily became an issue because of the failure to adjust corrosion inhibitors and disinfection that contributed 
A

Salinization along the Potomac River:
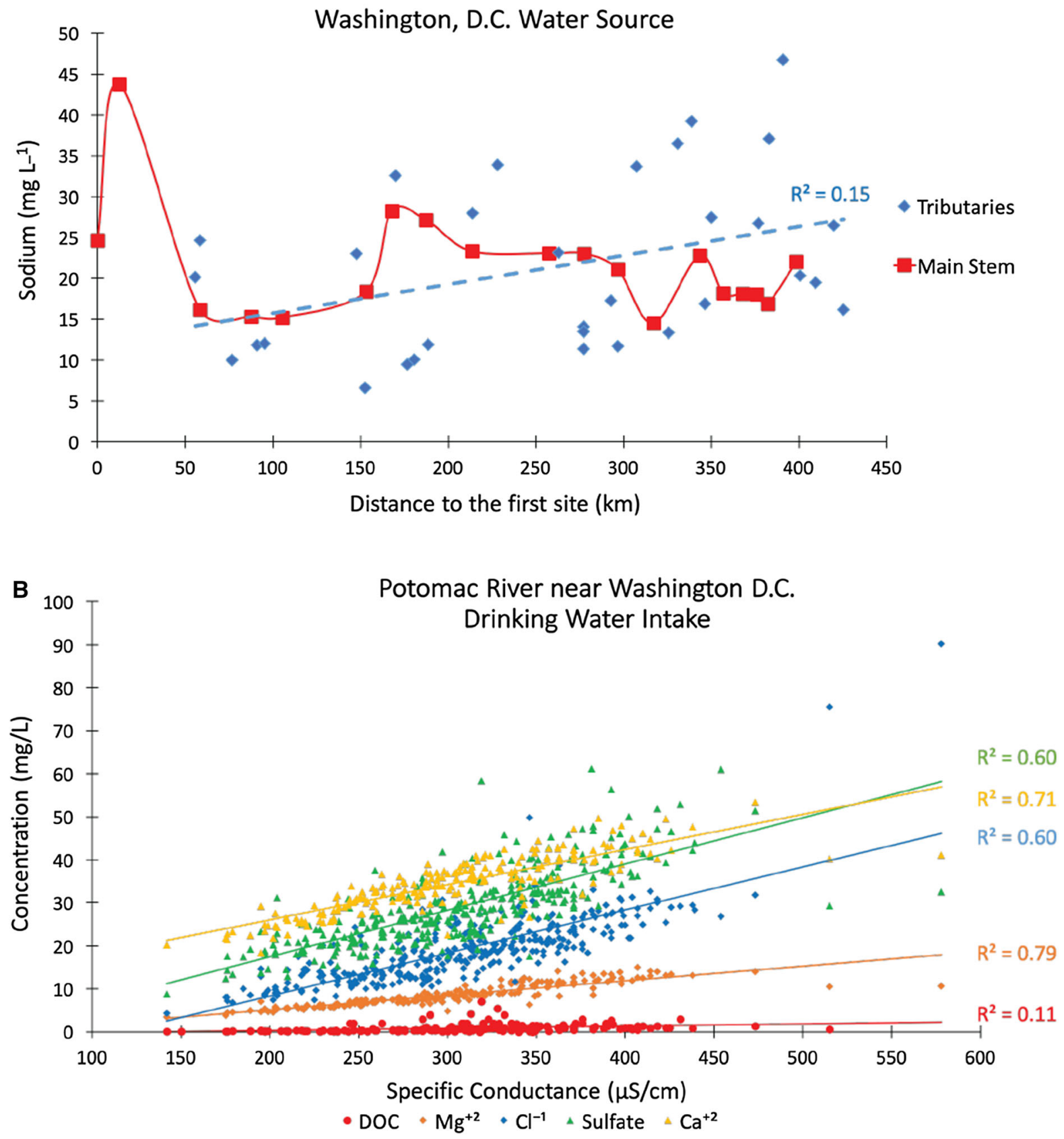

Fig. 3 Increasing sodium concentrations along the Potomac River mainstem and its tributaries, as it flows from its headwaters in West Virginia, USA to Washington, DC, USA (Top Panel). Linear relationships between specific conductance

to leaching of lead in pipes (Pieper et al. 2017). However, corrosive water from the Flint River, which was enriched in $\mathrm{Cl}^{-}$from road salts, also contributed and concentrations of multiple elements over decades in the Potomac River near the drinking water intake for the Washington, DC metropolitan region (USGS gage 01,646,580) (Bottom Panel)

to lead contamination from pipes throughout the city's water distribution system (Butler et al. 2016). Although the use of ferric chloride and the 
discontinuation of anti-corrosives were major contributors, increased $\mathrm{Cl}^{-}$and contributions to corrosion potential were also important. The failure of properly monitoring and reporting $\mathrm{Pb}$ and $\mathrm{Cu}$ concentrations in home drinking water taps was another factor that contributed to drinking water contamination. $\mathrm{Pb}$ in drinking water significantly affects children and pregnant women. Among infants who drink water with significant soluble $\mathrm{Pb}$ contamination, about $25 \%$ experience elevated blood $\mathrm{Pb}$ levels (Hanna-Attisha et al. 2016).

Increased salinization can damage drinking water infrastructure and leach contaminants (Novotny et al. 1998; Kaushal 2016). Increasing concentrations of $\mathrm{Cl}^{-}$is linked to corrosion of infrastructure and pipes and potential contamination of $\mathrm{Pb}$ throughout the US (Stets et al. 2018). Drinking water distribution systems that use galvanized steel or iron pipes are highly susceptible to corrosion by FSS, which may leach contaminants such as $\mathrm{Pb}$ and $\mathrm{Fe}$ (Stets et al. 2018). $\mathrm{Pb}$ pipe is also susceptible to leaching, and there can be leaching of $\mathrm{Pb}$ and other heavy metals from lead-tin solder joints in drinking water pipes (Edwards and Triantafyllidou 2007). Furthermore, $\mathrm{Cu}$ pipes are also susceptible to pitting induced by elevated concentrations of $\mathrm{Cl}^{-}$and $\mathrm{SO}_{4}{ }^{2-}$ in waters and soils (Stets et al. 2018). Experiments have shown that, as concentrations of salt ions increase, there is a corresponding increase in multiple metals mobilized in drinking water (Pieper et al. 2018).

Two chemical indices associated with corrosivity of plumbing and potential metal leaching are the $\mathrm{Cl}^{-}$ to $\mathrm{SO}_{4}{ }^{2-}$ mass ratio (CSMR) and the Larson ratio (LR). The CSMR is associated with galvanic corrosion of lead, and LR, the sum of $\mathrm{Cl}^{-}$and $\mathrm{SO}_{4}{ }^{2-}$ to bicarbonate $\left(\mathrm{HCO}_{3}{ }^{-}\right)$, is related to corrosivity of iron and steel (Lazur et al. 2020). Elevated corrosion from $\mathrm{Cl}^{-}$leads to formation of soluble $\mathrm{Pb}$ complexes and elevated $\mathrm{SO}_{4}{ }^{2-}$ leads to formation of insoluble $\mathrm{Pb}$ and $\mathrm{SO}_{4}{ }^{2-}$ complexes (Lazur et al. 2020). For example, in an attempt to treat water for elevated As by replacing $\mathrm{SO}_{4}{ }^{2-}$ with $\mathrm{Cl}^{-}$based treatment coagulants, there can be changes in the CSMR ratio (Edwards and Triantafyllidou 2007). Discontinuing the use of orthophosphate as the corrosion inhibitor, raised the CSMR ratio and caused $\mathrm{Pb}$ to leach in pipes in Flint, MI (Pieper et al. 2017).

Corrosion from road salts poses particular risk to private wells and drinking water infrastructure (Pieper et al. 2018). Corrosion from pipes in self-supplied groundwater in the USA contaminates drinking water with $\mathrm{Pb}$, calcite, and apatite, where about $15 \%$ of wells tested were at risk of $\mathrm{Pb}$ dissolution, and highest $\mathrm{Pb}$ concentrations were found in California, Maryland, and Pennsylvania (Jurgens et al. 2019). While $\mathrm{Pb}$ pipes are being phased out of use in the US and other developed nations, some drinking water infrastructure still relies on $\mathrm{Pb}$ pipes, and even plumbing systems without $\mathrm{Pb}$ pipes show calcite and apatite precipitates in pipes can leach $\mathrm{Pb}$ (Jurgens et al. 2019). More research is necessary regarding drinking water safety and the human health impacts of FSS.

Identifying risks of FSS based on presence of radionuclides and hydrogeology

Road salts can mobilize naturally occurring radioelements and represent a major risk to groundwater in cities where road density influences application which, in turn, is related to salt application quantity. Similar to many other examples of FSS contaminant mobilization discussed throughout this paper, redox, ionic strength, and $\mathrm{pH}$ are still important drivers of solubility of radionuclides. Geology is also important for the occurrence of various metals as well (Wright and Belitz 2010; Izbicki et al. 2015; McClain et al. 2019), except for the cosmogenic/fallout radionuclides (Gellis et al. 2020). In public drinking water wells across the USA, lead-210 and polonium-210 radionuclides contaminate aquifers used for drinking water (Szabo et al. 2020). The radionuclides $\mathrm{Pb}-210$ and Po-210 do not co-occur in groundwater despite both being derived from $\mathrm{Rn}-222$ due to control by decay rates and interactions with various aquifer materials such as the association of $\mathrm{Pb}-210$ with felsic crystalline rocks, whereas Po-210 presence is dictated by reducing conditions and high pH (Szabo et al. 2020).

Underlying hydrogeology can influence the movement and residence of subsurface $\mathrm{Cl}^{-}$contamination and transport of radionuclides. Chloride was highly persistent in fractured bedrock in Connecticut, USA and concentrations accumulated in groundwater over time due to road salts (Vitale et al. 2017). In the Northeastern US, $\mathrm{Na}^{+}$in groundwater was closely correlated with $\mathrm{Ra}$ while $\mathrm{Rn}$, the gaseous progeny of $\mathrm{Ra}$, decreased linearly with specific conductance, demonstrating the strong influence of salinity on mobilization of radionuclides of human health 
concern (McNaboe et al. 2017). Shallow groundwater can also be a reservoir for road salt in urban streams, which have chronically high $\mathrm{Cl}^{-}$levels throughout the year even after salt application suggesting retention of ions in soils and aquifers (Cooper et al. 2014). However, there can be complex hydrologic flowpaths that influence sources, fluxes, and flowpaths of salt ions and sediments in human-impacted watersheds (Gellis et al. 2020). Polluted return flows with salinized surface waters can enter groundwater resources in agricultural and urban systems with implications for contaminant mobilization. Given that road salts mobilize radionuclides and metal cations such as $\mathrm{Cu}, \mathrm{Pb}$, and $\mathrm{Zn}$ in groundwater (Norrström and Jacks 1998; Bäckström et al. 2004), more work is necessary to identify other contaminants along complex hydrogeologic flowpaths and the role of groundwater-surface water interactions.

Monitoring sources, peaks, and persistence of FSS using high-frequency sensors

High-frequency sensor data is becoming increasingly available for freshwaters around the world. Specific conductance can easily be measured by sensors and can be a proxy for nitrate concentrations and reveal shifting groundwater-surface water flowpaths in streams and rivers across the USA (Fig. 4). Continuous high-frequency sensor measurements can also allow investigation of research questions related to detection of peaks in salinity spanning different magnitudes, persistence of peaks and lag times in solute transport, characterizing the potential for comobilization of contaminants associated with episodic salinization, and hysteresis of salinity and chemical concentrations due to lag times in groundwater storage and contaminant flushing (Fig. 5) (Haq et al. 2018; Moore et al. 2019; Kaushal et al. 2019). Biomonitoring approaches may also be useful to track and record changes in major ions in freshwater environments (e.g. Piotrowski et al. 2020). Given that land use change and climate variability amplify contaminant pulses in many human-impacted streams, it is difficult to accurately quantify exceedances and violations in water quality with traditional grab sampling during fixed routine monitoring of growing water quality problems (Kaushal et al. 2014, 2019; Haq et al. 2018; Moore et al. 2019; Morel et al. 2020). In addition to anthropogenic inputs and human-accelerated weathering, the hydrology and volume of water available for dilution can influence the magnitude of salt pulses (refer to section Fundamental Geochemistry of Salinization - Making Chemical Cocktails below). Climate variability and changes in dry and wet years can interact with FSS and also influence the magnitude and duration of major ion pulses.

Sensor approaches are needed to interpolate and fill gaps between traditional grab sampling events to estimate concentrations across a wider range of hydrologic conditions in human-impacted watersheds and streams, particularly with flashy or pulsed hydrology (Kaushal et al. 2014; Morel et al. 2020). Thus, a growing research frontier will be to characterize and evaluate statistical relationships between high-frequency, continuous sensor outputs (e.g. specific conductance, water temperature, turbidity, nitrate, etc.) and individual water quality parameters such as salt ions, nutrients, and trace metals. In many regions throughout the USA, there has been an increasing density of US Geological Survey (USGS) stream gauges equipped with continuously recording water quality sensors. This makes it possible to relate traditional water quality measurements from grab samples, experiments, and laboratory measurements to "big data" sets of continuous sensor data of specific conductance (a robust proxy for dissolved ion concentrations) (Haq et al. 2018; Kaushal et al. 2018a). The analysis of sensor data will require developing new approaches to analyzing big data including statistical modeling and machine learning as well as to link concentrations and loads of salt ions, metals, and nutrients mobilized across seasons and events such as road deicer applications. Our work has shown that relationships between high-frequency sensor data can be developed to accurately estimate concentrations of salts, metals, and nutrients during wet weather storms and winter deicing events (Haq et al. 2018; Kaushal et al. 2019; Morel et al. 2020; Galella et al. 2021). More work is needed across different types of storms and snow events and broader gradients of streams and rivers across land use to more fully understand the impacts and consequences of these relationships (Haq et al. 2018; Morel et al. 2020; Galella et al. 2021). 

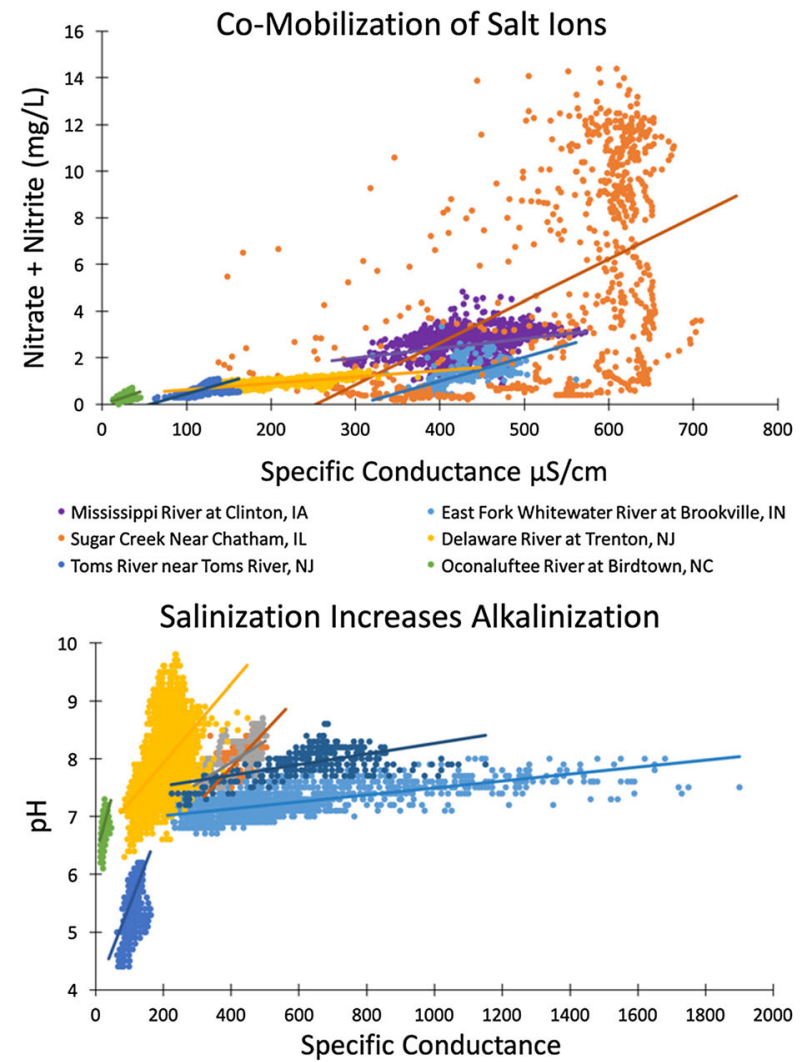

- East Fork Whitewater River at Brookville, IN - Big Muddy River at Rte 127 at Murphysboro, IL

- Big Raccoon Creek at Ferndale, IN - Oconaluftee River at Birdtown, NC

- Delaware River at Trenton, NJ - Toms River near Toms River, NJ

- Maumee River at Tecumseh Street at Fort Wayne, IN

Fig. 4 Specific conductance can be a useful proxy or tracer of hydrogeochemical concentrations, sources, and processes. For example, there are relationships between specific conductance and nitrate concentrations, $\mathrm{pH}$ and turbidity (which were all measured from high-frequency sensors) in surface waters throughout the USA. Positive relationships between nitrate + nitrite and specific conductance (a proxy for total dissolved solids) suggest co-mobilization of ions and formation of chemical cocktails. Negative relationships between nitrate + nitrite concentrations or turbidity and specific

\section{Part 4. Frontiers in managing freshwater salinization syndrome}

The environmental and health impacts of increased salt ions to fresh water from diverse sources is significant and should be reduced. There are many potential management options, but the most effective strategy is reducing salt loading. Unfortunately, the concentrations of many salt ions, including $\mathrm{Na}^{+}$and $\mathrm{Cl}^{-}$, are not regulated as primary contaminants in US drinking water (Kaushal 2016; Kaushal et al. 2018a). Yet, safe drinking water and secure water

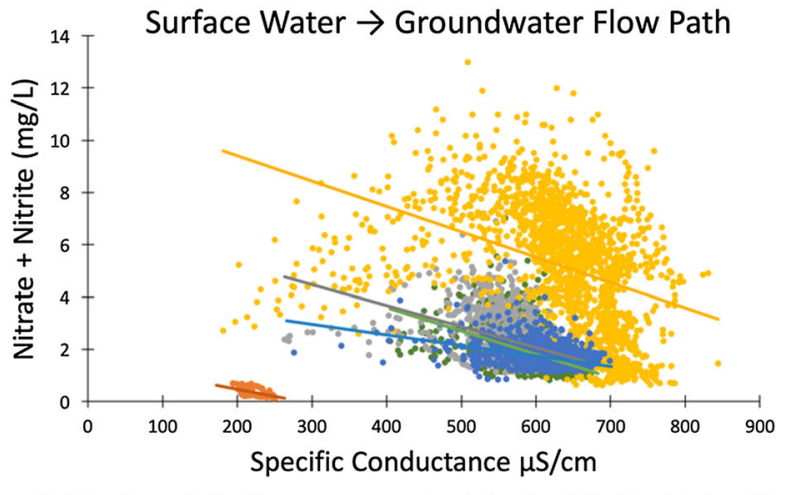

$\begin{array}{ll}\text { - Kankakee River at Shelby, IN } & \text {-Rough River Near Falls of Rough At Dam, KY } \\ \text { - Kankakee River at Dunns Bridge, IN } & \text { - Iroquois River Near Foresman, IN } \\ \text { - Kankakee River at Davis, IN } & \end{array}$

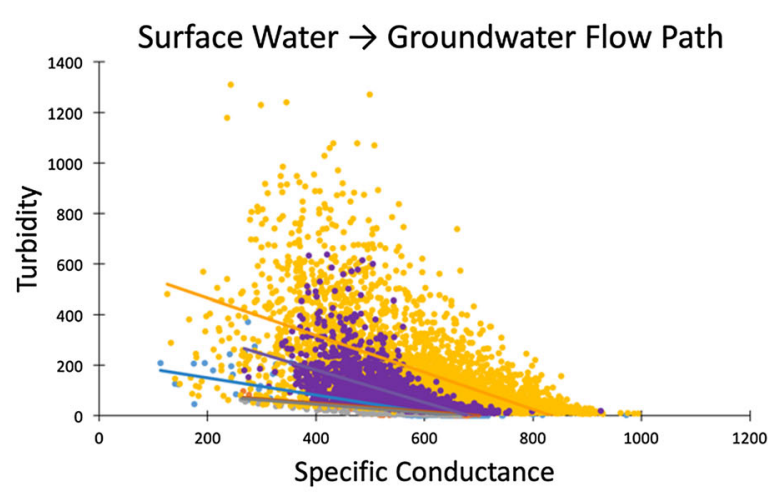

- East Fork Whitewater River at Richmond, IN - Kankakee River at Davis, IN

- Kankakee River at Dunns Bridge, IN - Missouri River at Hermann, MO

- Mississippi River at Cape Girardeau, MO

conductance indicate shifts from surface water to groundwater flowpaths (nitrate + nitrate concentrations and turbidity are highest in agricultural surface runoff from fertilized fields experiencing erosion and enhanced sediment transport; specific conductance is highest in deeper groundwater sources). Finally, salinization increases alkalinization, which is indicated by an increase in specific conductance (a proxy for total dissolved solids) and rise in $\mathrm{pH}$. All sites are from USGS Water Quality Watch, which provides continuous real-time water quality of surface water in the United States

infrastructure are a necessity. Diverse geological and anthropogenic sources of salt ions to fresh water make management of this problem especially challenging. Ultimately, there may be a need for regulations similar to the 1990 Clean Air Act Amendments, which were enacted to address pollution from acid rain (Likens 2010; Likens et al. 2021). Below, we discuss a few strategies for managing FSS. 

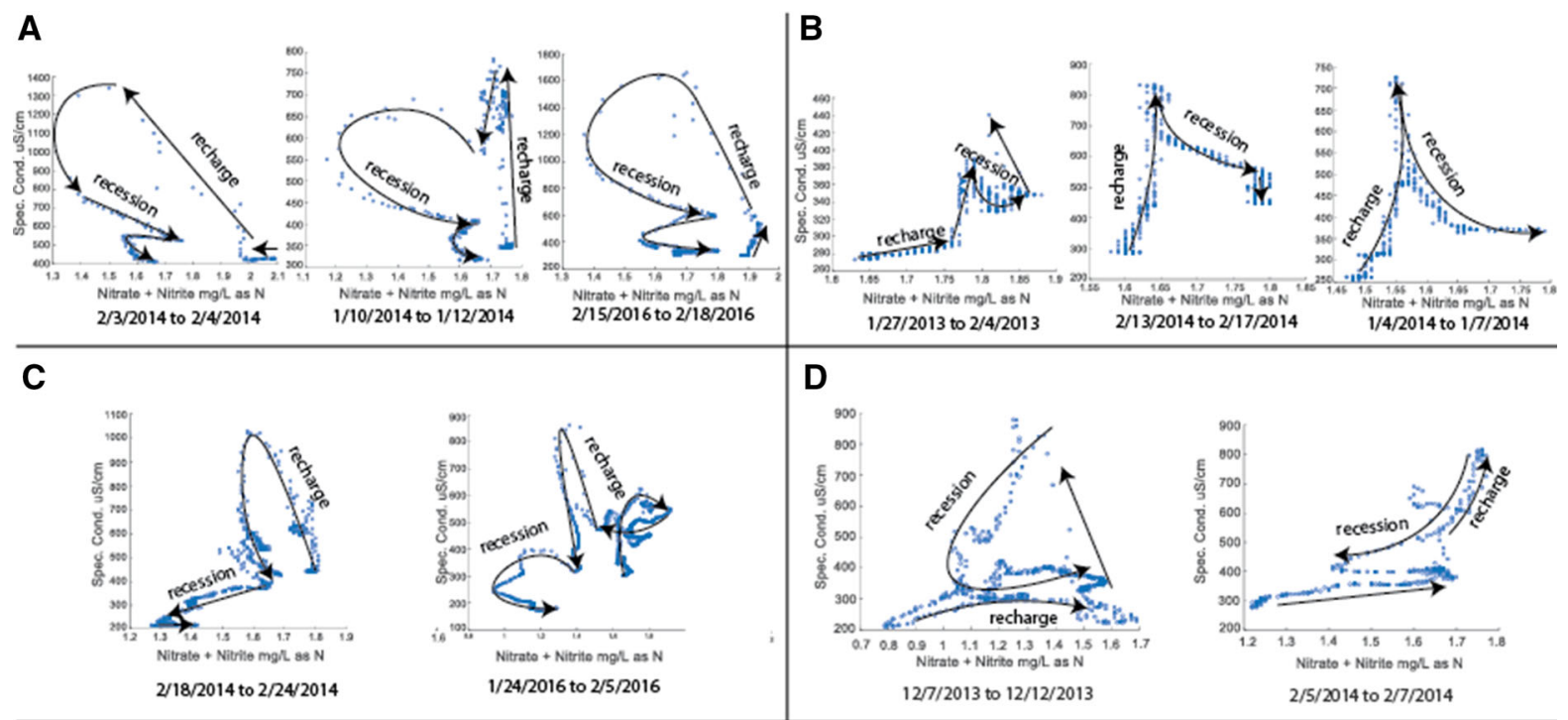

\section{D}
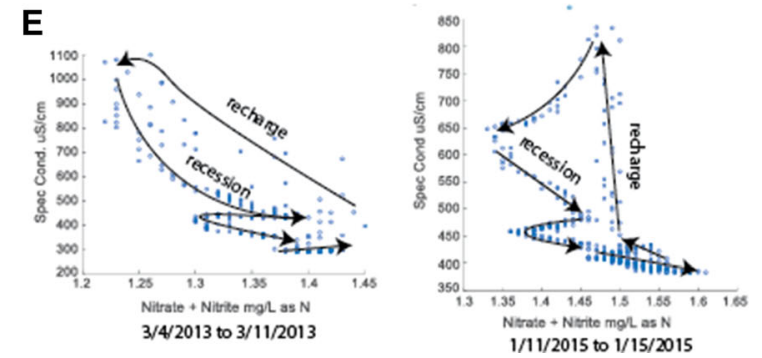

Fig. 5 Hysteresis in relationships between specific conductance and nitrate concentrations, which were all measured from highfrequency sensors in the Potomac River near the drinking water intake for the Washington, DC metropolitan region (USGS gage

Monitoring and managing FSS using a watershedecosystem approach

The watershed-ecosystem approach is a classic and widely used tool to evaluate transport, storage and transformation of nutrients and contaminants in ecological and hydrologic systems (Bormann and Likens 1967). This approach helps to evaluate and understand patterns, processes and recovery associated with ecosystem disturbances, such as acid rain, deforestation, climate change, land use change, etc. (Likens et al. 1970; Bormann and Likens 1979; Likens 2010, 2013; Holmes and Likens 2016). Several sources contributing to acid rain were recognized initially, but further studies showed that approximately $70 \%$ of sulfur dioxide was from fossil-fueled power plants in the Midwestern U.S. (Likens 2010, 2013; Likens et al. 2021). Mass balance studies of watershed-ecosystem inputs and outputs identified
01,646,580). Recharge of salt ions represents the ascending limb of the specific conductance peak during winter deicing events and recession represents the declining limb of the specific conductance peak

primary pollution sources that needed to be targeted to reduce the impact to lakes and rivers. Similar to acid rain, there are multiple sources of salt ion pollution associated with FSS and a coupled mass balance and watershed-ecosystem approach could also be used to evaluate and understand contributions from different sources and prioritize management efforts. For example, not every salt ion or nonpoint source is a major component of watershed salinity inputs and driver of increasing trends in freshwater ecosystems.

From a mass balance perspective, atmospheric deposition may be important for local or regional inputs of $\mathrm{H}^{+}$and salt ions only in some cases (Fig. 6). It is important to note that changes in the acidity of atmospheric inputs (Fig. 6), can influence weathering rates and recovery from acid rain, contributing to upward trends in major ions in freshwaters (Kaushal et al. 2013, 2018a; Stets et al. 2014). There have been 
increasing trends in atmospheric deposition of $\mathrm{Na}^{+}$ and $\mathrm{Cl}^{-}$ions in the coastal Northeastern USA, which may be due to aerosolization of road salts (automobiles driving over roads can suspend road salt ions into the atmosphere, and then salt ions are redeposited by precipitation) and/or changes in sea salt inputs from shifting storm patterns (Fig. 6). Some studies show localized atmospheric deposition of major ions in aerosols due to road salts during certain times of year (Blomqvist and Johansson 1999). There have also been increasing trends in $\mathrm{Ca}^{2+}$ in the Western USA, which may be due to increased eolian dust deposition from expansion of livestock grazing, increasing droughts and wildfires, and/or regional and long-range transport of dust from urban land use change and industrialization (Fig. 6). The initial focus of the watershed-ecosystem approach could be on mass balances of total dissolved solids including atmospheric, terrestrial and groundwater inputs, and the mass balance approach could be expanded or refined to estimate inputs of each salt ion to get a more complete budget for watersheds. More work is also necessary to understand the potential for localized "hot spots" of atmospheric deposition and aersolization of salt ions (e.g. $\mathrm{Na}^{+}$and $\mathrm{Cl}^{-}$), particularly near roadways and in response to ecosystem disturbances such as wildfires, urbanization, and agriculture. Ultimately, the watershed-ecosystem approach may be a way to understand, monitor, inventory sources, and manage salinity and secondary impacts related to mobilization of chemical cocktails.

\section{Trends in Atmospheric Ion Deposition in the U.S.}

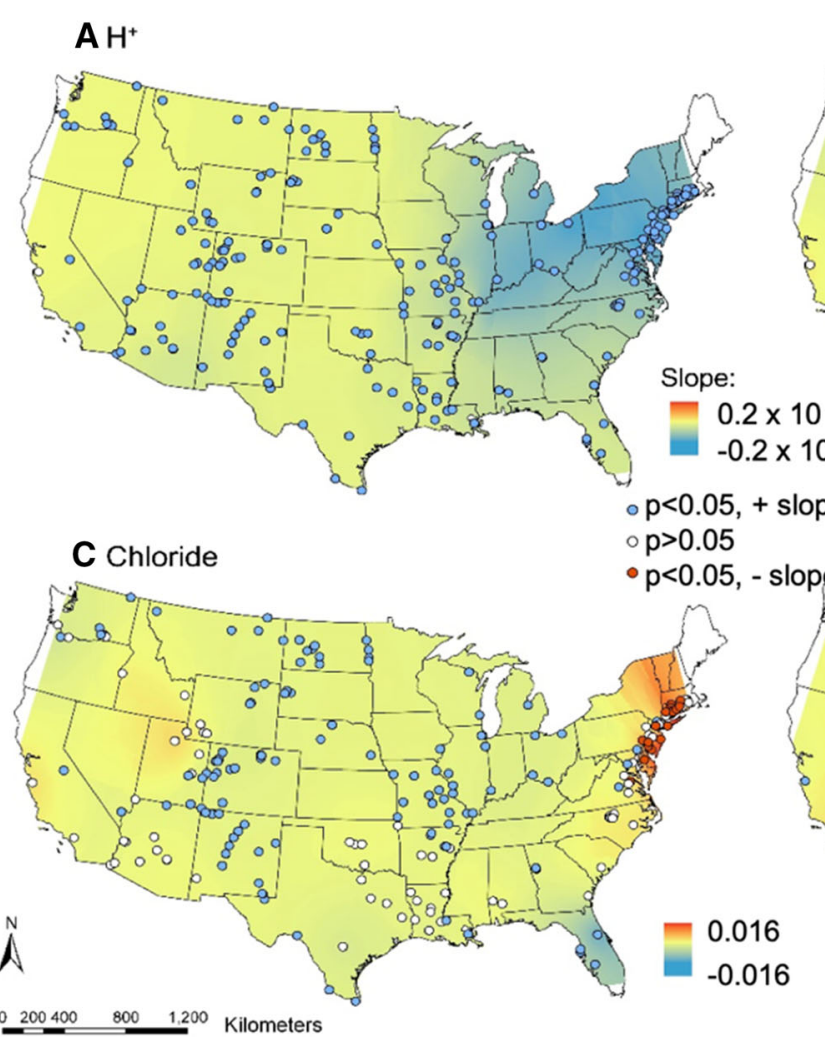

Fig. 6 Trends in $\mathrm{H}^{+}$and cation concentrations of rainwater in the continental United States. Points represent USGS monitoring stations analyzed in Kaushal et al. (2018a, b). We estimated changes in ionic deposition values in the watersheds at each site between 1986 to 2018 using data from interpolated maps provided by the National Atmospheric Deposition Program (NADP 2020). Trends for each watershed were approximated
B Sodium

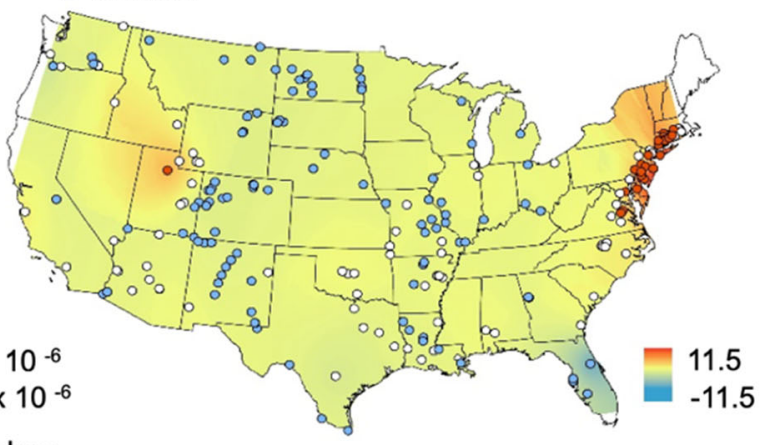

D Calcium

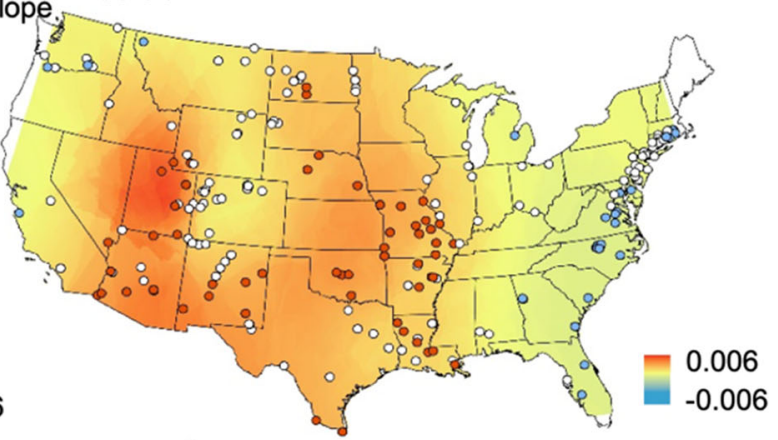

using Theil-Sen regression; red and blue values corresponding to statistically significantly increasing and decreasing trends, respectively, and white values indicate no statistically significant trend. Values were also interpolated among assessed sites to provide estimates of deposition trends throughout the continental United States 
Stormwater management retains and releases FSS chemical cocktails

There has been rapid expansion of engineered drainage networks in human-impacted landscapes which contribute to water quality issues via accelerated transport of nonpoint pollution sources to streams (Elmore and Kaushal 2008; Kaushal and Belt 2012; Kaushal et al. 2014). Depending on the type of stormwater management infrastructure, there is the potential to retain salt ions in soils, sediments, and groundwater but also to mobilize other contaminants concurrently through changes in ion exchange, $\mathrm{pH}$, and biogeochemical processes. For example, $\mathrm{Cl}^{-}$ levels were lower downgradient of permeable asphalt compared to upgradient in a small urban study impacted by high ambient $\mathrm{Cl}^{-}$concentrations, suggesting that permeable pavements, often employed to enhance infiltration in urban ecosystems (Passeport et al. 2013), may be a tool for managing groundwater quality (Dietz et al. 2017).

Plant-based bioremediation used in conjunction with stormwater management may also be effective for treating some metals in select soil strata (Rahman et al. 2016). For example, halophytes in the Atriplex genus and Typha angustifolia have been experimentally shown to significantly reduce the salinity of road runoff (Morteau et al. 2015; Suaire et al. 2016). In addition, these plant species also accumulated $\mathrm{Ni}$ and $\mathrm{Zn}$, which may further reduce some chemical cocktails of trace metals (Suaire et al. 2016). Salt concentrations in plant tissues reached their maximum after one week (Morteau et al. 2015). Further research will need to be conducted to examine the feasibility of phytoremediation approaches beyond the lab setting, across higher concentration ranges of salinity in wetlands and riparian zones, and the ultimate fate and disposal of contaminants after sequestration in plant biomass.

Stormwater management features including stream restoration can also influence mobilization of different salt ions, metals, and nutrients in response to FSS, but this has received less attention. Because stream restoration and stormwater management can enhance hydrologic connectivity and groundwater-surface water interactions (Kaushal et al. 2008; Newcomer Johnson et al. 2016), there can be plumes of salt ions that contaminate groundwater from enhanced infiltration or recharge (Cooper et al. 2014; Snodgrass et al. 2017). The concentrations and compositions of different salt ions and mobilization of secondary chemical cocktails in the soil profile in the plume can be directly related to groundwater table dynamics and recharge. Our previous work has shown that ion exchange induced by FSS can mobilize different ions (including toxic metals and nitrogen) from sediments into solution in streams and urban stormwater management sites (Fig. 7), and there are strong relationships between specific conductance and chemical cocktails of metals in urban streams (Fig. 8). Integration of certain media and substrates directly into soils in stormwater management features may enhance retention of certain metals and ions. For example, biochar application can increase $\mathrm{pH}$, alkalinity, and the high $\mathrm{P}$ and carbonate content of some biochars can reduce metal mobility or adsorb metals in micropores (Zhang et al. 2013; Novak et al. 2014) which, in turn, is driven by organic matter content and characteristics of soils (Uchimiya et al. 2010). Iron oxides have also been successfully used to reduce water solubility of As, Cd, Pb, and Zn (Komárek et al. 2013). Given that numbers and diversity of stormwater management features have rapidly increased and evolved over several decades (Kaushal et al. 2014), more research is needed regarding the retention and release of ions and contaminants in response to FSS and how changes in soils, sediments, and hydrogeology can alter the balance of these processes.

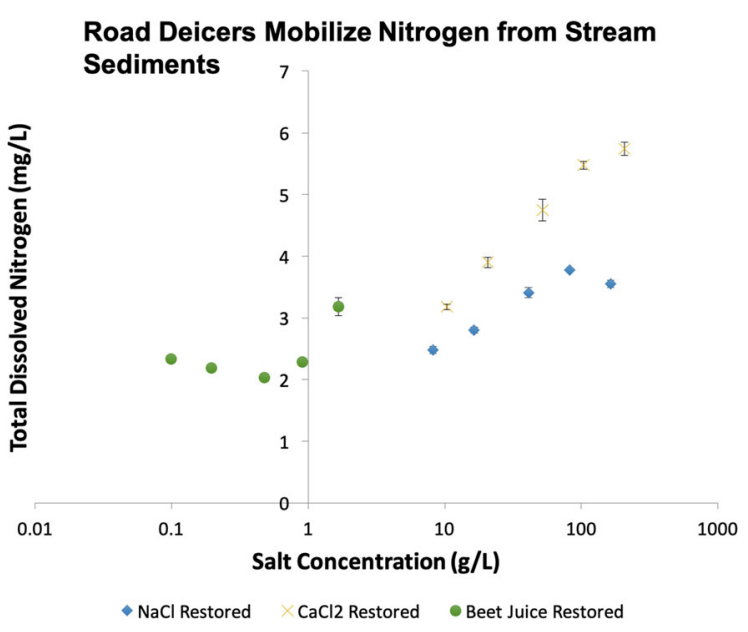

Fig. 7 Experimental effects of different deicers (sodium chloride, calcium chloride, and beet juice) at different concentrations in lab incubations on mobilization of nitrogen from sediments to stream water of a restored stream in Baltimore, MD. Methods are similar to Haq et al. 2018 and Kaushal et al. 2019 
Fig. 8 Relationships between specific conductance and concentrations of base cations and trace metals over several years in Paint Branch Creek and Campus Creek, which are two urban streams on the University of Maryland campus near Washington DC, USA
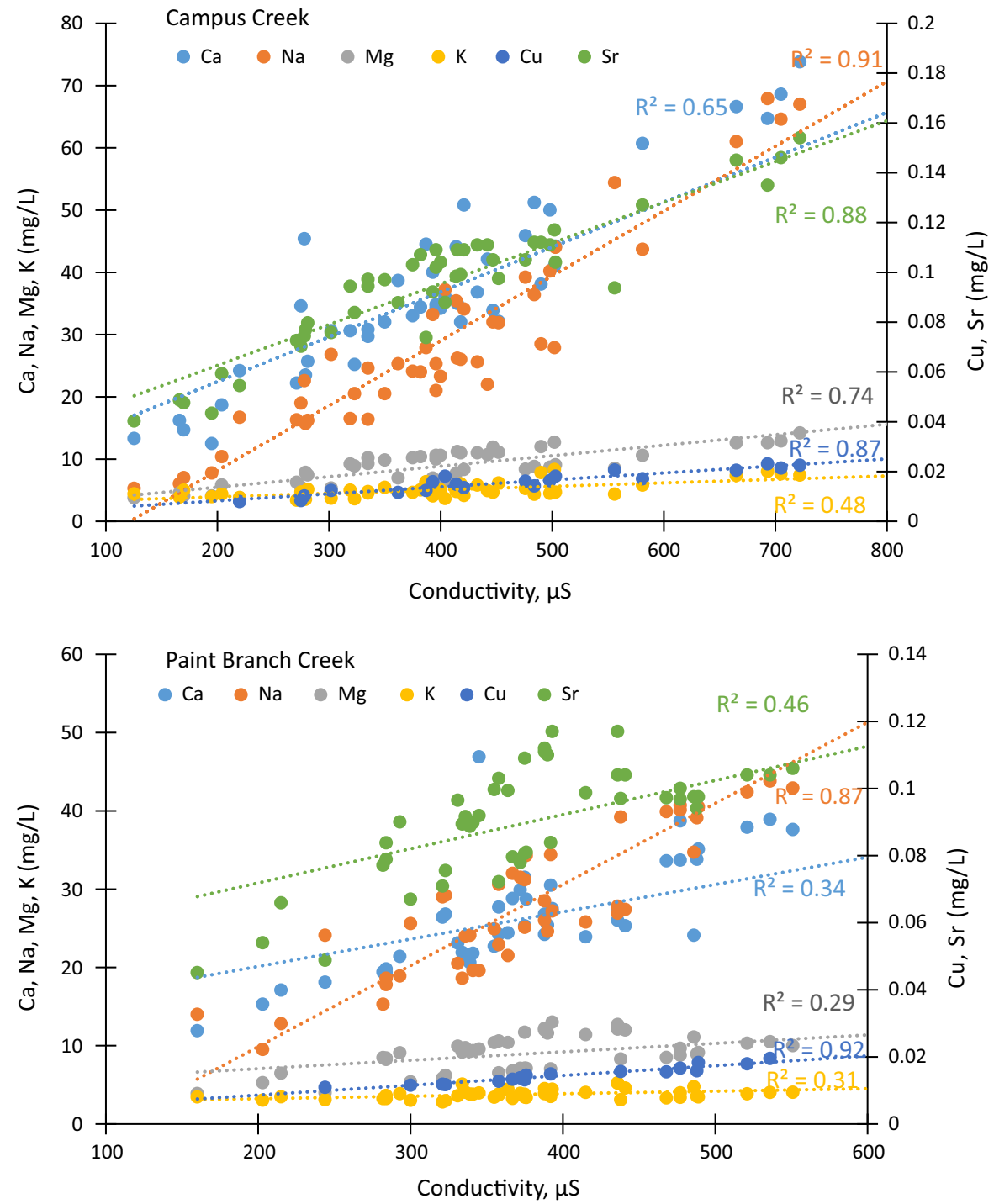

Managing FSS through groundwater remediation

Managing risks from FSS and associated chemical cocktails will depend upon identifying and characterizing the risk through rigorous groundwater studies which often require special drilling techniques and extensive hydrogeologic sampling, often over long time periods owing to slow subsurface movement of plumes. Above-ground management including reducing and controlling sources before they reach groundwater is a cheaper, more effective means of addressing risks to groundwater contamination. Once salt ions have entered groundwater resources, managing pollution and reducing risk to drinking water becomes more complicated.

When the extent and direction of salt ion plumes can be determined, treatment approaches can be implemented to halt or attenuate contaminants such as pump and treat solutions (Baú and Mayer 2008), thermal treatment (Stephenson et al. 2006), monitored natural attenuation (Wilkin 2008), and permeable reactive barriers (Ludwig et al. 2009; Wilkin et al. 2009). These efforts require proper location of the salt ion plume and positioning of treatment modes (e.g. permeable reactive barrier wall) to intercept the moving plume to allow interaction with microbes or chemicals such as zero valent iron or zeolites, which 
can react with and reduce transport of certain ions and chemical cocktails (Passeport et al. 2013). Other technologies to remove salt ions and chemical cocktails in groundwater include ion exchange, reverse osmosis, electrodialysis and capacitive deionization, an electrochemical technique that removes ions from solution via charged porous carbon electrodes. While certain technologies are targeted toward single contaminants, capacitive deionization may be especially effective at removing multiple contaminants such as $\mathrm{NO}_{3}{ }^{-}, \mathrm{PO}_{4}{ }^{3-}, \mathrm{Cr}^{6+}$, and $\mathrm{Cu}^{2+}$ even at low concentrations, an advantage when remediating multiple elements in chemical cocktails (Tang et al. 2016).

In-home reverse osmosis (RO) drinking water systems are effective $(>95 \%)$ at removing $\mathrm{Cl}^{-}$and other salts as well as heavy metals (Qdais and Moussa 2004), and also can effectively ( $>90 \%$ ) remove Ra, $\mathrm{U}$, and associated alpha and beta particles (USEPA 2005). However, such systems require maintenance and can be costly. In addition, there is also concern about reject brines from reverse osmosis systems (Ahmed et al. 2001; Imbulana et al. 2020). Contaminants and risk levels associated with groundwater and drinking water are not always known by the consumer due to lack of testing or local issues with decaying infrastructure and treatment (Schuler and Relyea 2018). Source control, addressing chemical cocktails comprehensively, and establishing effective regulations and management will be required to reduce the direct and indirect risks of Freshwater Salinization Syndrome.

\section{Managing FSS from road salt runoff}

As indicated throughout this paper, the causes and consequences of FSS and its chemical cocktails are more diverse than previously recognized. Here, we highlight the potential diversity of approaches to address one of the most ubiquitous and voluminous sources of salt ions contributing to FSS in temperate regions, road deicers (i.e. Jackson and Jobbagy 2005; Kaushal et al. 2005). Other FSS management solutions warrant further discussion, but we focus on this topic because it is an emerging issue.

\section{Brines and pre-wetting to manage FSS from road salts}

Rock salt $(\mathrm{NaCl})$ has been the traditional solution to addressing road safety in winter by melting snow and ice on the road surface by lowering the freezing point of water. Rock salt is only effective at temperatures above $-6{ }^{\circ} \mathrm{C}$ and decreases in effectiveness as temperature decreases to $-21^{\circ} \mathrm{C}$. Brining is a practice intended to reduce the amount of salt needed to deice roads, in which a salt solution is applied to roads as preventative best management practice (BMP) before a forecasted winter storm (Haake and Knouft 2019). Brining can reduce average chloride transport to streams by $\sim 45 \%$ under some circumstances (Haake and Knouft 2019). Another method is pre-wetting rock salt, as it is applied to the road, which accelerates the temperature reduction process in breaking the bond between the snow and pavement (Koefod et al. 2015). Pre-wetting rock salt not only increases the rate of melting, but also helps rock salt stay on the ground (Koefod et al. 2015).

\section{Traction sands to manage FSS on roadways}

Traction sand is another alternative deicer used to make roads accessible for cars in case of snow where sand is mixed with salt before being applied to roadways (Pulley et al. 2010). Another important advantage of using sand is that it can create a minor albedo effect to warm pavement and melt surrounding ice, and it can also perform well in extremely cold weather (Hossain et al. 1997). $\mathrm{MgCl}$, a more effective deicer than $\mathrm{NaCl}$ at lower temperatures, can be added to sand before being applied to roads. Potential drawbacks of using sand include accumulation and runoff which can impact water quality (Pulley et al. 2010). Traction sand also contains contaminants such as $\mathrm{Cu}, \mathrm{Zn}, \mathrm{Cl}, \mathrm{Mg}, \mathrm{Na}, \mathrm{N}$, and $\mathrm{P}$ that can contribute to stormwater runoff (Pulley et al. 2010).

\section{Alternatives to sodium chloride to manage FSS on roadways}

Road salt alternatives to $\mathrm{NaCl}$ have been suggested as a management approach for stormwater runoff, but some alternate road deicers such $\mathrm{MgCl}_{2}$ and $\mathrm{CaCl}_{2}$ are still highly efficient mobilizers of $\mathrm{Pb}, \mathrm{Cd}$, and $\mathrm{Cu}$ (Acosta et al. 2011). In addition, the $\mathrm{NaCl}$ and $\mathrm{CaCl}_{2^{-}}$ based road salts cause corrosion in both the concrete and steel structures on bridges, roadways, and sidewalks (Tang and Lindvall 2012; Gode and Paeglitis 2014) leading to risk of failure and potential for injuries and fatalities. Interestingly, self-heating 
concrete mixtures are being tested as an alternative to applying road salts for deicing (Farnam et al. 2017). Another experimental approach is the use of Sporosarcina pasteuria bacteria to reduce the formation of calcium oxychloride when $\mathrm{CaCl}$ in road salt reacts with the calcium hydroxide $\left(\mathrm{Ca}(\mathrm{OH})_{2}\right.$ in concrete (Jones et al. 2020). These bacteria, commonly found in soil, convert nutrients and $\mathrm{Ca}$ into $\mathrm{CaCO}_{3}$ or calcite, thereby reducing the corrosion potential of the road salt.

Biochar, produced from pyrolysis of organic matter usually sourced from waste streams including poultry litter or wood by-products, is a relatively inexpensive engineered solution that can help manage FSS effects in urban, agricultural, and other contaminated soils. Biochar has been found to mitigate or even eliminate salt stress in some plant species (Thomas et al. 2013). For example, biochar additions reduced the effects of salt-induced mortality in Abutilon theophrasti and increased survival of Prunella vulgaris (Thomas et al. 2013). Biochar can enhance water retention, cation exchange capacity, and carbon sequestration (Thomas et al. 2013), which may offset impacts of FSS.

Other alternative options include organic salts such as various acetate mixtures including potassium acetate, calcium magnesium acetate, sodium acetate, sodium formate, and proprionate salts. Potassium acetate is sometimes used because it is less corrosive when relative to $\mathrm{NaCl}$ (Xie et al. 2017), though it still causes corrosion of galvanized steel (Xie et al. 2017). While organic salt ions cause less corrosion of steel than $\mathrm{NaCl}$, the effects on concrete were similar across both traditional and organic road salts (Xie et al. 2017). For example, $\mathrm{Ca} \mathrm{Mg}$ acetate (CMA) causes aggressive degradation of concrete when used during freeze-thaw cycles (Lee et al. 2000). A disadvantage of CMA is the degradation of the finer aggregate particles within concrete, which could more easily wash into waterways and contribute to salinity (Lee et al. 2000). Cheese whey can also be used to create acetate salts like CMA and propionate salts at a low cost through fermentation (Praveen et al. 2007). Organic molecules such as sugars, lignins, and hemicellulose can also lower water's freezing point, preventing ice crystal formation. Various industrial sources of organic wastes have been proposed as salt alternatives for deicing. For example, beet juice, a product of the sugar industry, can lower water's freezing point (Fu et al. 2012), and outperform some road salts at lower temperatures (Gerbino-Bevins et al. 2012). Although beet juice is not toxic to aquatic life, it contains organic matter, which can contribute to biochemical oxygen demand, and it also has the potential to mobilize nitrogen into solution (Fig. 7).

Managing FSS through regulations

Another strategy for managing FSS may be through improved water quality regulations. Countries and regions around the world manage water quality using diverse strategies. There have been debates regarding bottom up vs. top down management approaches for managing freshwater salinization in the past (CañedoArgüelles et al. 2013a, 2016a; Kaushal 2016; Schuler et al. 2019). Future work in the social sciences may need to investigate the effectiveness of personal or market-based forces $v s$. regulations as a means of managing FSS. Although there may be many regulatory questions beyond the scope of this study, we highlight a few urgent needs from the US. For example, there is a current lack of private well testing, which hampers detection of impacts on domestic drinking water. Approximately 42 million Americans rely on private well systems for their main source of water (Colley et al. 2019). Some states in the USA have mandatory private well testing laws but performing treatment on contaminated wells can be optional (Flanagan et al. 2018). A USGS study found that 25 states are vulnerable to having corrosive wells due to unregulated water (Belitz et al. 2016). Given the extensive impacts of FSS on groundwater resources discussed in this paper, the lack of private well testing may contribute to a serious emerging environmental and health issue. In addition, chlorides are not federally regulated in the US as primary contaminants in drinking water, although $\mathrm{Na}^{+}$is currently being considered. For drinking water, the USEPA recommends that chloride concentrations remain below $250 \mathrm{mg} / \mathrm{L}$ and recommended levels for $\mathrm{Na}^{+}$concentrations are $20 \mathrm{mg} / \mathrm{L}$, and decreasing salinity may decrease hypertension in some consumers (Schmidt 2017). Currently, $\mathrm{Na}^{+}$and $\mathrm{Cl}^{-}$in drinking water is not regulated by USEPA under national primary water quality regulations for human health but rather, only non-regulatory values to address aesthetic effects and aquatic life criteria. In order to reduce risks and protect human health, $\mathrm{Na}^{+}$and $\mathrm{Cl}^{-}$could potentially be considered as mandatory regulated substances and 
Table 3 Geochemical signatures of a variety of nonpoint sources of salt contributing to Freshwater Salinization Syndrome (FSS)

\begin{tabular}{|c|c|c|}
\hline Common FSS Source & Geochemical Signatures & References \\
\hline Road Salt & $\begin{array}{l}\text { Element: } \mathrm{Cl} \\
\text { Ratios: Major ions, } \mathrm{Br} / \mathrm{Cl}, \mathrm{Na} / \mathrm{Cl}, \mathrm{SO}_{4} / \mathrm{Cl} \text {, } \\
{ }^{37} \mathrm{Cl} / \mathrm{Cl} \text {, } \\
\text { Tracers: dye }\end{array}$ & $\begin{array}{l}\text { (Kreitler 1993; Vengosh 2005; Nassery } \\
\text { and Kayhomayoon 2013) }\end{array}$ \\
\hline Wastewater and Sewage & $\begin{array}{l}\text { Element: } \mathrm{N}, \mathrm{Cl} \\
\text { Ratios: }{ }^{87} \mathrm{Sr} /{ }^{86} \mathrm{Sr}, \mathrm{Cl} / \mathrm{Br}, \mathrm{Na} / \mathrm{Cl}, \mathrm{Br} / \mathrm{Cl}, \mathrm{B} / \mathrm{Cl}\end{array}$ & (Vengosh 2005; Moore et al. 2008) \\
\hline Oil field brines & $\begin{array}{l}\text { Element: } \mathrm{Cl} \\
\text { Ratios: }{ }^{37} \mathrm{Cl} / \mathrm{Cl}, \mathrm{Na} / \mathrm{Cl}, \mathrm{Br} / \mathrm{Cl} \\
\text { Isotope: } \delta 7 \mathrm{Li}\end{array}$ & $\begin{array}{l}\text { (Mirzavand et al. 2020; McDevitt et al. } \\
\text { 2020) }\end{array}$ \\
\hline $\begin{array}{l}\text { Agriculture effluent (irrigation } \\
\text { and fertilizer) }\end{array}$ & $\begin{array}{l}\text { Element: } \mathrm{SO}_{4}, \mathrm{NO}_{3}{ }^{-}, \mathrm{B} \\
\text { Ratio: }{ }^{87} \mathrm{Sr} /{ }^{86} \mathrm{Sr}\end{array}$ & $\begin{array}{l}\text { (Trabelsi et al. 2007; Kume et al. 2010; } \\
\text { Ben Ammar et al. 2020) }\end{array}$ \\
\hline Seawater Intrusion & $\begin{array}{l}\text { Element: } \mathrm{B}, \mathrm{Ba}, \mathrm{I}, \mathrm{Cl} \\
\text { Ratio: } \mathrm{B} / \mathrm{Cl}, \mathrm{Cl} / \mathrm{Br}, \mathrm{Na} / \mathrm{Cl} \text {, Simpson's ratio } \\
\text { Isotope: } \delta \mathrm{D}-\delta^{18} \mathrm{O},{ }^{14} \mathrm{C},{ }^{3} \mathrm{H} \text {, }\end{array}$ & $\begin{array}{l}\text { (Sánchez-Martos et al. 2002; Nassery and } \\
\text { Kayhomayoon 2013; Abdalla 2016) }\end{array}$ \\
\hline Evaporite Dissolution & $\begin{array}{l}\text { Element: } \mathrm{Na}, \mathrm{Cl} \\
\text { Ratio: } \mathrm{Na} / \mathrm{Cl}, \mathrm{Br} / \mathrm{Cl}, \mathrm{Li} / \mathrm{Cl}, \mathrm{Mn} / \mathrm{Cl}, \mathrm{B} / \mathrm{Li} \text {, } \\
\text { Cl/TDS, B/CL, }{ }^{87} \mathrm{Sr} /{ }^{86} \mathrm{Sr}\end{array}$ & (Bouchaou et al. 2008; Zarei et al. 2013) \\
\hline
\end{tabular}

Geochemical signatures include elements, elemental ratios, and isotopes

Total Daily Maximum Loads (TMDLs) could be enforced under the federal Clean Water Act. Given that specific conductance can be related to a wide variety of ions as shown throughout this paper, further work may be needed to identify and manage FSS impacts at the level of chemical cocktails or mixtures relevant to watersheds or regions. Overall, much work is necessary to explore the effectiveness of different regulatory frameworks for FSS (and other comprehensive approaches and options discussed throughout this paper) as potential management tools by social scientists, politicians, environmental agencies, and/or the public.

Emerging research and management questions

Our review and analysis highlight several emerging research and management topics, but many questions remain. For example, uncertainty exists around how different salt ions and mixtures ranging from low to higher salinities impact biota, ecological communities, and ecosystem functions and services (Schuler and Relyea 2018; Iglesias 2020). Some species may be more sensitive to specific ions and chemical cocktails and questions remain about which species are affected, which are extirpated, and what would be the effects on ecosystems? For example, what are emerging threats to those organisms adapted to waters with lower salinity because of increased ion pollution? Biotic diversity and changes in species abundances, changes in species roles, and distributions need to be identified. In addition, some salts are micronutrients, and salt ions may subsidize primary production, microbial and ecosystem metabolism, and nutrient uptake. All of this information can be useful in better understanding the importance of controlling FSS to protect aquatic life and also ecosystem functions and services related to clean drinking water.

In addition, there are questions related to FSS and associated chemical cocktails and estimating the relative contributions of road salt ions, fertilizers, construction activities that disturb soils, humanaccelerated weathering processes, water softeners, and others discussed in this paper. How do these different salt sources shift seasonally, across hydrologic flowpaths, across varying degrees of groundwater-surface water interactions, along different irrigation return flow cycles, along engineered drainage networks, and across different types and gradients of developed land use? Can we use different 
geochemical tracers to track salinization sources and quantify relative contributions of FSS (Table 3)? More work using geochemical measurements of major and trace elements and their isotopes is necessary to investigate sources, fluxes, and flowpaths of salt ions and associated chemical cocktails in watersheds (Table 3). For example, the catchment/watershed approach can be used to characterize major sources and fluxes of ions exported from small end-member watersheds reflecting a dominant land use. Changes in the sources and transformations of salt ions can also be analyzed across broader spatial scales and watershed sizes using stable isotopic techniques coupled with process-level measurements in streams and continuous sensor measurements (e.g. Haq et al. 2018; Kaushal et al. 2019; Morel et al. 2020; Galella et al. 2021). Information on sources, fluxes, and transformations of salt ions in watersheds can be linked to complementary geochemical measurements in paleocological studies, soil cores, and groundwater, or simulation models to understand how past land use interacts with present day processes to influence sources, fluxes and flowpaths of FSS chemical cocktails. These approaches may reveal the importance of legacy impacts and how long they last in watersheds across land use, stream order, soils, and topography.

There are many questions related to emerging impacts of FSS and chemical cocktails on aquatic life, clean drinking water, infrastructure, use of water for energy and food production, etc. Most salinization research has focused almost exclusively on $\mathrm{Na}^{+}$or $\mathrm{Cl}^{-}$; however, there can be different ions and ionic ratios. For example, how do $\mathrm{Mg}^{2+}$ and $\mathrm{Cl}^{-}$ratios at similar levels to $\mathrm{Na}^{+}$and $\mathrm{Cl}^{-}$or $\mathrm{Na}^{+}$and $\mathrm{SO}_{4}{ }^{2-}$, and other ions and ratios relate to different impacts on species diversity, toxicity, corrosion potential, crop production, and water quality issues? Further, how can the ecological stoichiometry of a diversity of salt ions and chemical cocktails in freshwaters be connected to the diversity of microbial, plant, and animal species and water quality impacts on corrosion and scaling of pipes, contaminant toxicity, and microbial processes, etc. For example, some mixtures of salt ions may have lesser impacts on aquatic species, but they may mobilize toxic metals in drinking water pipes and/or create more scaling on pipes used in power generation and transmitting steam. Previous work has almost exclusively focused on the "cocktail" or "mixture effect" from toxicology (Cross et al. 2001; Celander
2011; Adebambo et al. 2015; Svingen and Vinggaard 2016). Throughout this paper, we have illustrated the need for a watershed chemical cocktail concept to encompass more holistic changes in salinized fresh water (e.g. Kaushal et al. 2018a, b, 2019, 2020; Morel et al. 2020; Galella et al. 2021). This concept can help investigate many emerging questions regarding whether different salt ions and chemical cocktails have environmental trade-offs, interactions, and unintended consequences that we haven't identified and/or predicted yet.

Ultimately, ecosystem scale experiments, advances in water quality monitoring approaches using highfrequency sensors, and models are necessary to advance research and management frameworks for predicting what happens when we increase salinity and shift chemical composition of salt ion mixtures. For example, if we are interested in studying or managing freshwaters and the salinity is doubled, tripled, quadrupled, etc. with specific ions in the future, can we accurately predict direct and indirect effects of FSS on biodiversity, water quality, corrosion potential, nutrient and metals mobilization, etc.? Developing conceptual and quantitative frameworks for predicting what could happen in the future can significantly improve management efforts and identify what we need to do to protect, restore and mitigate damage to freshwater ecosystems.

Similarly, management of FSS must develop into a cohesive, coordinated approach involving legislation at local and regional scales, source control of major inputs of salt ions, technological solutions to cleanup of surface and groundwater, alternatives to deicer salts, and investigation into corrosion control of drinking water infrastructure and roads and bridges, and new methods of stormwater control that attenuate rather than exacerbate FSS impacts.

\section{Conclusions}

Our comprehensive review and analysis suggest that FSS is increasing dramatically across certain regions globally. Impacts on safe drinking water, human health, aquatic life, infrastructure, and other far ranging impacts remain poorly understood and require further research and management in future decades. In particular, FSS needs to come under coordinated management effort to alleviate increasing 
environmental, infrastructure, and human health consequences. If this complicated, emerging problem doesn't get the attention it deserves, FSS will likely increase in severity and put tremendous pressure on existing freshwater resources. Most importantly, we propose that FSS now needs to be considered a pervasive problem of ecosystem and infrastructure degradation, water security, and human health at the same level as acid rain, eutrophication, loss of biodiversity, and other mainstream, environmental issues. Freshwater is one of our most precious resources, and our comprehensive review and analysis has shown that it is becoming seriously degraded with multiple ions and chemical cocktails across global, regional, and local scales. If increasing trends in freshwater salinization continue, there are serious risks that freshwater will not be as "fresh" or have the same desired chemical, biological, and physical properties, and/or be able to provide the same ecosystem services as in previous decades. Recognizing that FSS is becoming one of the most pervasive, and systemic water quality problems of this century can change the ways we think about it, study it, and manage it into the future.

Acknowledgements This special anniversary issue paper is dedicated to Dr. M. This project would not have been possible without his deep thoughts, insights, contributions, and support over years. Very few times in life, are we fortunate to come across such exceptional and trustworthy collaborators and friends. Tamara Newcomer Johnson and two anonymous reviewers provided helpful comments that significantly improved this manuscript. Ray Weil, Stanley Grant, and Karl Berger provided helpful discussions. We thank the NADP and USGS for providing data online.

Author contributions Study concept and design and drafting of initial manuscript (SK, GL, MP, JR, CM); Data analyses (JR, CM, JG, SD, RU, JK, AY, WB, NB, SH, KW); Text contributions (JK, BW, CEP, DC, BYA, TG, SC, JW, CB, $\mathrm{CB}, \mathrm{MD}, \mathrm{DG}, \mathrm{SH}, \mathrm{GK}, \mathrm{EQ}, \mathrm{CR}, \mathrm{MT}, \mathrm{HW}$, and SW).

Funding This work was supported by: National Science Foundation EAR 1521224 and GCR 2021089, Maryland Sea Grant SA75281870W, Pooled Monitoring Initiative led by the Chesapeake Bay Trust, Water Research Foundation, and the Washington Metropolitan Council of Governments contract \# 21-001.

\section{Declarations}

Conflict of interest The authors have no relevant financial or non-financial interests to disclose.
Open Access This article is licensed under a Creative Commons Attribution 4.0 International License, which permits use, sharing, adaptation, distribution and reproduction in any medium or format, as long as you give appropriate credit to the original author(s) and the source, provide a link to the Creative Commons licence, and indicate if changes were made. The images or other third party material in this article are included in the article's Creative Commons licence, unless indicated otherwise in a credit line to the material. If material is not included in the article's Creative Commons licence and your intended use is not permitted by statutory regulation or exceeds the permitted use, you will need to obtain permission directly from the copyright holder. To view a copy of this licence, visit http://creativecommons.org/licenses/by/4.0/.

\section{References}

Abbaslou H, Hadifard H, Ghanizadeh AR (2020) Effect of cations and anions on flocculation of dispersive clayey soils. Heliyon 6:e03462. https://doi.org/10.1016/j.heliyon. 2020.e03462

Abdalla F (2016) Ionic ratios as tracers to assess seawater intrusion and to identify salinity sources in Jazan coastal aquifer Saudi Arabia. Arab J Geosci 9:12

Acosta JA, Jansen B, Kalbitz K et al (2011) Salinity increases mobility of heavy metals in soils. Chemosphere 85:1318-1324. https://doi.org/10.1016/j.chemosphere. 2011.07.046

Adebambo OA, Ray PD, Shea D, Fry RC (2015) Toxicological responses of environmental mixtures: Environmental metal mixtures display synergistic induction of metal-responsive and oxidative stress genes in placental cells. Toxicol Appl Pharmacol 289:534-541. https://doi.org/10.1016/j.taap. 2015.10.005

Ahmed M, Shayya WH, Hoey D, Al-Handaly J (2001) Brine disposal from reverse osmosis desalination plants in Oman and the United Arab Emirates. Desalination 133:135-147. https://doi.org/10.1016/S0011-9164(01)80004-7

Ali S, Thakur SK, Sarkar A, Shekhar S (2016) Worldwide contamination of water by fluoride. Environ Chem Lett 14:291-315. https://doi.org/10.1007/s10311-016-0563-5

Allen JD (1985) Stream Ecology Structure and Function of Running Waters. Chapman \& Hall, Firs, p 1

Anning DW, Flynn ME (2014) Dissolved-solids sources, loads, yields, and concentrations in streams of the conterminous United States. US Geological Survey

Aota Y, Kumagai M, Ishikawa K (2003) Over twenty years trend of chloride ion concentration in Lake Biwa. J Limnol 62:42. https://doi.org/10.4081/jlimnol.2003.s1.42

Apaydın A, Aktaş SD (2012) Assessment of groundwater quality of the Tatlicay aquifer and relation to the adjacent evaporitic formations (Cankiri, Turkey). Environ Monit Assess 184:2337-2357. https://doi.org/10.1007/s10661011-2121-8

Appelo CAJ, Postma D (2004) Geochemistry, Groundwater and Pollution. CRC Press

Ardón M, Helton A, Bernhardt E (2016) Drought and saltwater incursion synergistically reduce dissolved organic carbon 
export from coastal freshwater wetlands. Biogeochemistry 127:411-426. https://doi.org/10.1007/s10533-016-0189-5

Bäckström M, Karlsson S, Bäckman L et al (2004) Mobilisation of heavy metals by deicing salts in a roadside environment. Water Res 38:720-732. https://doi.org/10.1016/j.watres. 2003.11.006

Barlow PM, Reichard EG (2010) Saltwater intrusion in coastal regions of North America. Hydrogeol J 18:247-260. https://doi.org/10.1007/s10040-009-0514-3

Baú DA, Mayer AS (2008) Optimal design of pump-and-treat systems under uncertain hydraulic conductivity and plume distribution. J Contam Hydrol 100:30-46. https://doi.org/ 10.1016/j.jconhyd.2008.05.002

Belitz K, Jurgens BC, Johnson TD (2016) Potential corrosivity of untreated groundwater in the United States. US Geological Survey

Ben Ammar S, Taupin J-D, Ben Alaya M et al (2020) Using geochemical and isotopic tracers to characterize groundwater dynamics and salinity sources in the Wadi Guenniche coastal plain in northern Tunisia. J Arid Environ 178:104150. https://doi.org/10.1016/j.jaridenv.2020. 104150

Bernhardt ES, Palmer MA (2011) The environmental costs of mountaintop mining valley fill operations for aquatic ecosystems of the Central Appalachians. Ann N Y Acad Sci 1223:39-57

Bhide S, Grant S, Parker E, et al (2020) Addressing the Contribution of Indirect Potable Reuse to Inland Freshwater Salinization

Blomqvist G, Johansson E-L (1999) Airborne spreading and deposition of de-icing salt-a case study. Sci Total Environ 235:161-168

Bormann FH, Likens GE (1967) Nutrient Cycling. Science 155:424-429. https://doi.org/10.1126/science.155.3761. 424

Bormann FH, Likens G (1979) Pattern and Process in a Forested Ecosystem: Disturbance, Development and the Steady State Based on the Hubbard Brook Ecosystem Study. Springer, New York

Bouchaou L, Michelot JL, Vengosh A et al (2008) Application of multiple isotopic and geochemical tracers for investigation of recharge, salinization, and residence time of water in the Souss-Massa aquifer, southwest of Morocco. J Hydrol 352:267-287. https://doi.org/10.1016/j.jhydrol. 2008.01.022

Braithwaite F (1855) On the infiltration of salt-water into the springs of wells under london and liverpool. Minutes of the Proceedings of the Institution of Civil Engineers 14:507-509. https://doi.org/10.1680/imotp.1855.23921

Bubeck RC, Diment WH, Deck BL et al (1971) Runoff of deicing salt: effect on Irondequoit Bay, Rochester, New York. Science 172:1128-1132

Burow KR, Belitz K, Dubrovsky NM, Jurgens BC (2017) Large decadal-scale changes in uranium and bicarbonate in groundwater of the irrigated western U.S. Sci Total Environ 586:87-95. https://doi.org/10.1016/j.scitotenv.2017. 01.220

Butler LJ, Scammell MK, Benson EB (2016) The flint, michigan, water crisis: a case study in regulatory failure and environmental injustice. Environmental Justice 9:93-97. https://doi.org/10.1089/env.2016.0014
Calabrese EJ, Tuthill RW (1977) A review of literature to support a sodium drinking water standard. J Environ Health 40:80-83

Campeau A, Wallin MB, Giesler R et al (2017) Multiple sources and sinks of dissolved inorganic carbon across Swedish streams, refocusing the lens of stable C isotopes. Sci Rep 7:9158. https://doi.org/10.1038/s41598-017-09049-9

Cañedo-Argüelles M, Kefford BJ, Piscart C et al (2013a) Salinisation of rivers: an urgent ecological issue. Environ Pollut 173:157-167

Cañedo-Argüelles M, Hawkins C, Kefford BJ et al (2016a) Saving freshwater from salts. Science 351:914-916

Cañedo-Argüelles M, Sala M, Peixoto G et al (2016b) Can salinity trigger cascade effects on streams? A mesocosm approach. Sci Total Environ 540:3-10

Canton JH, Wester PW, Mathijssen-Spiekman EAM (1983) Study on the toxicity of sodium bromide to different freshwater organisms. Food Chem Toxicol 21:369-378. https://doi.org/10.1016/0278-6915(83)90090-X

Carpenter SR, Caraco NF, Correll DL et al (1998) Nonpoint pollution of surface waters with Phosphorus and Nitrogen. Ecol Appl 8:559-568. https://doi.org/10.1890/10510761(1998)008[0559:NPOSWW]2.0.CO;2

Cassanelli JP, Robbins GA (2013) Effects of road salt on Connecticut's groundwater: A statewide centennial perspective. J Environ Qual 42:737-748

Celander MC (2011) Cocktail effects on biomarker responses in fish. Aquat Toxicol 105:72-77. https://doi.org/10.1016/j. aquatox.2011.06.002

Chowdhury S, Mazumder MAJ, Al-Attas O, Husain T (2016) Heavy metals in drinking water: occurrences, implications, and future needs in developing countries. Sci Total Environ 569-570:476-488. https://doi.org/10.1016/j.scitotenv. 2016.06.166

Colley SK, Kane PK, MacDonald Gibson J (2019) Risk Communication and Factors Influencing Private Well Testing Behavior: A Systematic Scoping Review. Int J Environ Res Public Health 16:4333

Connor NP, Sarraino S, Frantz DE et al (2014) Geochemical characteristics of an urban river: Influences of an anthropogenic landscape. Appl Geochem 47:209-216. https:// doi.org/10.1016/j.apgeochem.2014.06.012

Cooper CA, Mayer PM, Faulkner BR (2014) Effects of road salts on groundwater and surface water dynamics of sodium and chloride in an urban restored stream. Biogeochemistry 121:149-166. https://doi.org/10.1007/s10533014-9968-z

Corsi SR, Graczyk DJ, Geis SW et al (2010) A fresh look at road salt: aquatic toxicity and water-quality impacts on local, regional, and national scales. Environ Sci Technol 44:7376-7382. https://doi.org/10.1021/es101333u

Councell TB, Duckenfield KU, Landa ER, Callender E (2004) Tire-wear particles as a source of zinc to the environment. Environ Sci Technol 38:4206-4214. https://doi.org/10. 1021/es034631f

Cross DP, Ramachandran G, Wattenberg EV (2001) Mixtures of Nickel and Cobalt Chlorides induce synergistic cytotoxic effects: implications for inhalation exposure modeling. Ann Occup Hyg 45:409-418. https://doi.org/10.1093/ annhyg/45.5.409 
D'Alessandro W, Bellomo S, Parello F et al (2008) Survey on fluoride, bromide and chloride contents in public drinking water supplies in Sicily (Italy). Environ Monit Assess 145:303-313. https://doi.org/10.1007/s10661-007-0039-y

Das DK, Islam MdS, Hadiujjaman S et al (2019) Health cost of salinity contamination in drinking water: evidence from Bangladesh. Environ Econ Policy Stud 21:371-397. https://doi.org/10.1007/s10018-018-0234-9

de Oliveira-Filho EC, Lopes RM, Paumgartten FJR (2004) Comparative study on the susceptibility of freshwater species to copper-based pesticides. Chemosphere 56:369-374. https://doi.org/10.1016/j.chemosphere.2004. 04.026

DeSimone LA, McMahon PB, Rosen MR (2014) The quality of our Nation's waters: Water quality in principal aquifers of the United States, 1991-2010. U.S. Geological Survey, Reston, VA

DeVore CL, Rodriguez-Freire L, Mehdi-Ali A et al (2019) Effect of bicarbonate and phosphate on arsenic release from mining-impacted sediments in the Cheyenne River watershed, South Dakota, USA. Environmental Science: Processes \& Impacts 21:456-468. https://doi.org/10.1039/ C8EM00461G

Dieter CA, Maupin MA, Caldwell RR et al (2018) Estimated use of water in the United States in 2015: US Geological Survey Circular 1441, US Department of the Interior. US Geological Survey, Washington, DC

Dietz ME, Angel DR, Robbins GA, McNaboe LA (2017) Permeable Asphalt: A New Tool to Reduce Road Salt Contamination of Groundwater in Urban Areas. Groundwater 55:237-243. https://doi.org/10.1111/gwat.12454

DiGiulio DC, Wilkin RT, Miller C, Oberley G (2011) Investigation of ground water contamination near Pavillion, Wyoming

Drever J (1988) The Geochemistry of Natural Waters: Surface and Groundwater Environments. Prentice-Hall, New Jersey

Duarte S, Pascoal C, Alves A et al (2008) Copper and zinc mixtures induce shifts in microbial communities and reduce leaf litter decomposition in streams. Freshw Biol 53:91-101

Dugan HA, Bartlett SL, Burke SM et al (2017) Salting our freshwater lakes. Proc Natl Acad Sci 114:4453-4458

Dugan H, Skaff NK, Doubek JP et al (2020) Lakes at risk of chloride contamination. Environmental Science \& Technology. https://doi.org/10.1021/acs.est.9b07718

Edwards M, Triantafyllidou S (2007) Chloride-to-sulfate mass ratio and lead leaching to water. Journal AWWA 99:96-109. https://doi.org/10.1002/j.1551-8833.2007. tb07984.x

Elmore AJ, Kaushal SS (2008) Disappearing headwaters: patterns of stream burial due to urbanization. Front Ecol Environ 6:308-312

Environmental Protection Department of HKSAR River Water Quality Data. The Government of the Hong Kong Special Administrative Region

Erickson ML, Yager RM, Kauffman LJ, Wilson JT (2019) Drinking water quality in the glacial aquifer system, northern USA. Sci Total Environ 694:133735. https://doi. org/10.1016/j.scitotenv.2019.133735
Farnam Y, Esmaeeli HS, Zavattieri PD et al (2017) Incorporating phase change materials in concrete pavement to melt snow and ice. Cement Concr Compos 84:134-145. https:// doi.org/10.1016/j.cemconcomp.2017.09.002

Farrell EP (1995) Atmospheric deposition in maritime environments and its impact on terrestrial ecosystems. Water Air Soil Pollut 85:123-130. https://doi.org/10.1007/ BF00483694

Fay L, Shi X (2012) Environmental Impacts of Chemicals for Snow and Ice Control: State of the Knowledge. Water Air Soil Pollut 223:2751-2770. https://doi.org/10.1007/ s11270-011-1064-6

Feistel R, Wielgosz R, Bell SA et al (2015) Metrological challenges for measurements of key climatological observables: oceanic salinity and $\mathrm{pH}$, and atmospheric humidity. Part 1: overview. Metrologia 53:R1-R11. https://doi.org/ 10.1088/0026-1394/53/1/R1

Ferreira V, Koricheva J, Duarte S et al (2016) Effects of anthropogenic heavy metal contamination on litter decomposition in streams-a meta-analysis. Environ Pollut 210:261-270

Ferronato C, Marinari S, Francioso O et al (2019) Effect of waterlogging on soil biochemical properties and organic matter quality in different salt marsh systems. Geoderma 338:302-312. https://doi.org/10.1016/j.geoderma.2018.12. 019

Flanagan SV, Gleason JA, Spayd SE et al (2018) Health protective behavior following required arsenic testing under the New Jersey Private Well Testing Act. Int J Hyg Environ Health 221:929-940

Fontenot BE, Hunt LR, Hildenbrand ZL et al (2013) An Evaluation of Water Quality in Private Drinking Water Wells Near Natural Gas Extraction Sites in the Barnett Shale Formation. Environ Sci Technol 47:10032-10040. https:// doi.org/10.1021/es4011724

Foster SA, Pennino MJ, Compton JE et al (2019) Arsenic Drinking Water Violations Decreased across the United States Following Revision of the Maximum Contaminant Level. Environ Sci Technol 53:11478-11485. https://doi. org/10.1021/acs.est.9b02358

Fu L, Omer R, Jiang C (2012) Field test of organic deicers as prewetting and anti-icing agents for winter road maintenance. Transp Res Rec 2272:130-135

Gaillardet J, Viers J, Dupre B 5.09 Trace Elements in River Waters. 48

Galella JG, Kaushal SS, Wood KL et al (2021) Sensors track mobilization of 'chemical cocktails' in streams impacted by road salts in the Chesapeake Bay watershed. Environ Res Lett. https://doi.org/10.1088/1748-9326/abe48f

Garg VK, Suthar S, Singh S et al (2009) Drinking Water Quality in Villages of Southwestern Haryana, India: Assessing Human Health Risks Associated with Hydrochemistry. Environ Geol 58:1329-1340

Gellis AC, Fuller CC, Van Metre PC et al (2020) Pavement alters delivery of sediment and fallout radionuclides to urban streams. J Hydrol 588:124855. https://doi.org/10. 1016/j.jhydrol.2020.124855

Gerbino-Bevins B, Tuan CY, Mattison M (2012) Evaluation of ice-melting capacities of deicing chemicals. J Test Eval 40:952-960 
Ghadimi F, Ghomi M, Azimi R (2016) Sources of Nitrate and Bromide Contaminants in Groundwater of the Alluvial Aquifer of Arak. Iran 8:18

Gode K, Paeglitis A (2014) Concrete Bridge Deterioration Caused by De-Icing Salts in High Traffic Volume Road Environment in Latvia. The Baltic Journal of Road and Bridge Engineering 9:200-207. https://doi.org/10.3846/ bjrbe. 2014.25

Godwin K, Hafner S, Buff M (2003) Long-term trends in sodium and chloride in the Mohawk River, New York: the effect of fifty years of road-salt application. Environ Pollut 124:273-281

Goldberg S, Forster HS (1990) Flocculation of Reference Clays and Arid-Zone Soil Clays. Soil Sci Soc Am J 54:714-718. https://doi.org/10.2136/sssaj1990. $03615995005400030014 x$

González CM, Aristizábal BH (2012) Acid rain and particulate matter dynamics in a mid-sized Andean city: The effect of rain intensity on ion scavenging. Atmos Environ 60:164-171. https://doi.org/10.1016/j.atmosenv.2012.05. 054

Good KD, VanBriesen JM (2016) Current and Potential Future Bromide Loads from Coal-Fired Power Plants in the Allegheny River Basin and Their Effects on Downstream Concentrations. Environ Sci Technol 50:9078-9088. https://doi.org/10.1021/acs.est.6b01770

Gozzard E, Mayes WM, Potter HAB, Jarvis AP (2011) Seasonal and spatial variation of diffuse (non-point) source zinc pollution in a historically metal mined river catchment, UK. Environ Pollut 159:3113-3122. https://doi.org/10. 1016/j.envpol.2011.02.010

Haake DM, Knouft JH (2019) Comparison of Contributions to Chloride in Urban Stormwater from Winter Brine and Rock Salt Application. Environ Sci Technol 53:11888-11895

Hanna-Attisha M, LaChance J, Sadler RC, Champney Schnepp A (2016) Elevated Blood Lead Levels in Children Associated With the Flint Drinking Water Crisis: A Spatial Analysis of Risk and Public Health Response. Am J Public Health 106:283-290. https://doi.org/10.2105/AJPH.2015. 303003

Haq S, Kaushal SS, Duan S (2018) Episodic salinization and freshwater salinization syndrome mobilize base cations, carbon, and nutrients to streams across urban regions. Biogeochemistry 141:463-486

Hellar-Kihampa H, De Wael K, Lugwisha E, Van Grieken R (2013) Water quality assessment in the Pangani River basin, Tanzania: natural and anthropogenic influences on the concentrations of nutrients and inorganic ions. International Journal of River Basin Management 11:55-75. https://doi.org/10.1080/15715124.2012.759119

Helton AM, Bernhardt ES, Fedders A (2014) Biogeochemical regime shifts in coastal landscapes: the contrasting effects of saltwater incursion and agricultural pollution on greenhouse gas emissions from a freshwater wetland. Biogeochemistry 120:133-147. https://doi.org/10.1007/s10533014-9986-x

Herndon EM, Jin L, Brantley SL (2011) Soils Reveal Widespread Manganese Enrichment from Industrial Inputs. Environ Sci Technol 45:241-247. https://doi.org/10.1021/ es102001w
Hinckley E-LS, Crawford JT, Fakhraei H, Driscoll CT (2020) A shift in sulfur-cycle manipulation from atmospheric emissions to agricultural additions. Nat Geosci 13:597-604

Hintz WD, Mattes BM, Schuler MS et al (2017) Salinization triggers a trophic cascade in experimental freshwater communities with varying food-chain length. Ecol Appl 27:833-844

Holmes RT, Likens GE (2016) Hubbard Brook: The Story of a Forest Ecosystem. Yale University Press, London

Hossain MM, Bajorski P, Yang W-S (1997) Frictional characteristics of sand and sand-deicer mixtures on bare ice. Transp Res Rec 1585:30-38

Huizenga JM, Silberbauer M, Dennis R, Dennis I (2013) Technical note: An inorganic water chemistry dataset (1972-2011) of rivers, dams and lakes in South Africa. Water SA 39:335-340. https://doi.org/10.4314/wsa.v39i2. 18

Huling EE, Hollocher TC (1972) Groundwater contamination by road salt: Steady-state concentrations in East Central Massachusetts. Science 176:288-290

Hussein AH, Rabenhorst MC, Tucker ML (2004) Modeling of Carbon Sequestration in Coastal Marsh Soils. Soil Sci Soc Am J 68:1786-1795. https://doi.org/10.2136/sssaj2004. 1786

Iglesias MC-A (2020) A review of recent advances and future challenges in freshwater salinization. Limnetica 39:185-211

Imbulana S, Oguma K, Takizawa S (2020) Evaluation of groundwater quality and reverse osmosis water treatment plants in the endemic areas of Chronic Kidney Disease of Unknown Etiology (CKDu) in Sri Lanka. Sci Total Environ 745:140716. https://doi.org/10.1016/j.scitotenv.2020. 140716

Izbicki JA, Wright MT, Seymour WA et al (2015) Cr(VI) occurrence and geochemistry in water from public-supply wells in California. Appl Geochem 63:203-217. https:// doi.org/10.1016/j.apgeochem.2015.08.007

Jackson RB, Jobbagy EG (2005) From icy roads to salty streams. Proc Natl Acad Sci 102:14487-14488

Jackson RB, Vengosh A, Darrah TH et al (2013) Increased stray gas abundance in a subset of drinking water wells near Marcellus shale gas extraction. PNAS 110:11250-11255. https://doi.org/10.1073/pnas.1221635110

Jackson RB, Vengosh A, Carey JW et al (2014) The Environmental Costs and Benefits of Fracking. Annu Rev Environ Resour 39:327-362. https://doi.org/10.1146/annurevenviron-031113-144051

Jacobsen T, Adams RM (1958) Salt and Silt in Ancient Mesopotamian Agriculture. Science 128:1251-1258

Johnson AR, Munoz A, Gottlieb JL, Jarrard DF (2007) High Dose Zinc Increases Hospital Admissions Due to Genitourinary Complications. J Urol 177:639-643. https://doi. org/10.1016/j.juro.2006.09.047

Jones C, Ramanathan S, Suraneni P, Hale WM (2020) Calcium oxychloride: A critical review of the literature surrounding the formation, deterioration, testing procedures, and recommended mitigation techniques. Cement Concr Compos 113:103663. https://doi.org/10.1016/j.cemconcomp.2020. 103663

Jurgens BC, Parkhurst DL, Belitz K (2019) Assessing the Lead Solubility Potential of Untreated Groundwater of the 
United States. Environ Sci Technol 53:3095-3103. https:// doi.org/10.1021/acs.est.8b04475

Kang M, Jackson RB (2016) Salinity of deep groundwater in California: Water quantity, quality, and protection. PNAS 113:7768-7773. https://doi.org/10.1073/pnas. 1600400113

Kashef A-AI (1972) WHAT DO WE KNOW ABOUT SALT WATER INTRUSION? JAWRA Journal of the American Water Resources Association 8:282-293

Kaushal SS (2016) Increased salinization decreases safe drinking water. Environ Sci Technol. https://doi.org/10.1021/ acs.est.6b00679

Kaushal SS, Belt KT (2012) The urban watershed continuum: evolving spatial and temporal dimensions. Urban Ecosystems 15:409-435

Kaushal SS, Groffman PM, Likens GE et al (2005) Increased salinization of fresh water in the northeastern United States. Proc Natl Acad Sci 102:13517-13520

Kaushal SS, Groffman PM, Mayer PM et al (2008) Effects of stream restoration on denitrification in an urbanizing watershed. Ecol Appl 18:789-804

Kaushal SS, Likens GE, Jaworski NA et al (2010) Rising stream and river temperatures in the United States. Front Ecol Environ 8:461-466

Kaushal SS, Likens GE, Utz RM et al (2013) Increased river alkalinization in the Eastern US. Environ Sci Technol 47:10302-10311

Kaushal SS, McDowell WH, Wollheim WM (2014) Tracking evolution of urban biogeochemical cycles: past, present, and future. Biogeochemistry 121:1-21

Kaushal SS, McDowell WH, Wollheim WM et al (2015) Urban evolution: The role of water. Water 7:4063-4087

Kaushal SS, Duan S, Doody TR et al (2017) Human-accelerated weathering increases salinization, major ions, and alkalinization in fresh water across land use. Appl Geochem 83:121-135. https://doi.org/10.1016/j.apgeochem.2017. 02.006

Kaushal SS, Likens GE, Pace ML et al (2018a) Freshwater salinization syndrome on a continental scale. PNAS 115:E574-E583. https://doi.org/10.1073/pnas. 1711234115

Kaushal SS, Likens GE, Pace ML, Utz RM (2018b) US rivers are becoming saltier - and it's not just from treating roads in winter. In: Salon. https://www.salon.com/2018/04/27/ us-rivers-are-becoming-saltier-and-it-is-not-just-fromtreating-roads-in-winter_partner/. Accessed 24 Feb 2021

Kaushal SS, Likens GE, Pace ML et al (2019) Novel 'chemical cocktails' in inland waters are a consequence of the freshwater salinization syndrome. Philosophical Transactions of the Royal Society B: Biological Sciences 374:20180017. https://doi.org/10.1098/rstb.2018.0017

Kaushal SS, Wood KL, Galella JG et al (2020) Making 'chemical cocktails' - Evolution of urban geochemical processes across the periodic table of elements. Appl Geochem 119:104632. https://doi.org/10.1016/j. apgeochem.2020.104632

Kelly VR, Lovett GM, Weathers KC et al (2008) Long-term sodium chloride retention in a rural watershed: legacy effects of road salt on streamwater concentration. Environ Sci Technol 42:410-415

Kelly W, Panno S, Hackley K (2012) Impacts of Road Salt Runoff on Water Quality of the Chicago, Illinois, Region.
Environ Eng Geosci 18:65-81. https://doi.org/10.2113/ gseegeosci.18.1.65

Kelly VR, Findlay SE, Hamilton SK et al (2019) Seasonal and long-term dynamics in stream water sodium chloride concentrations and the effectiveness of road salt best management practices. Water Air Soil Pollut 230:13

Khan AE, Ireson A, Kovats S et al (2011) Drinking Water Salinity and Maternal Health in Coastal Bangladesh: Implications of Climate Change. Environ Health Perspect 119:1328-1332. https://doi.org/10.1289/ehp.1002804

Kharak YK, Thordsen JJ, Conaway CH, Thomas RB (2013) The Energy-Water Nexus: Potential Groundwater-Quality Degradation Associated with Production of Shale Gas. Procedia Earth and Planetary Science 7:417-422. https:// doi.org/10.1016/j.proeps.2013.03.132

Kharaka YK, Otton JK (2007) Preface to special issue on environmental issues related to oil and gas production. Appl Geochem 22:2095-2098. https://doi.org/10.1016/j. apgeochem.2007.04.006

Kirwan ML, Gedan KB (2019) Sea-level driven land conversion and the formation of ghost forests. Nat Clim Chang 9:450-457. https://doi.org/10.1038/s41558-019-0488-7

Knobeloch L, Ziarnik M, Anderson H, Proctor M (1994) Gastrointestinal upsets associated with ingestion of coppercontaminated water. Environmental Health Perspectives. https://doi.org/10.1289/ehp.94102958

Koefod S, Mackenzie R, Adkins J (2015) Effect of Prewetting Brines on the Ice-Melting Rate of Salt at Very Cold Temperatures. Transp Res Rec 2482:67-73

Komárek M, Vaněk A, Ettler V (2013) Chemical stabilization of metals and arsenic in contaminated soils using oxides - A review. Environ Pollut 172:9-22. https://doi.org/10.1016/j. envpol.2012.07.045

Kondash AJ, Redmon JH, Lambertini E et al (2020) The impact of using low-saline oilfield produced water for irrigation on water and soil quality in California. Sci Total Environ 733:139392. https://doi.org/10.1016/j.scitotenv.2020. 139392

Krause L, Klumpp E, Nofz I et al (2020) Colloidal iron and organic carbon control soil aggregate formation and stability in arable Luvisols. Geoderma 374:114421. https:// doi.org/10.1016/j.geoderma.2020.114421

Kreitler CW (1993) Geochemical Techniques for Identifying Sources of Ground-Water Salinization. CRC Press

Krumgalz BS, Magdal E, Starinsky A (2002) The evolution of a chloride sedimentary sequence-simulated evaporation of the Dead Sea. Israel J Earth Sci 51:253-267. https://doi. org/10.1560/EL8J-PVU9-EH88-M083

Kshetrimayum KS, Hegeu H (2016) The state of toxicity and cause of elevated Iron and Manganese concentrations in surface water and groundwater around Naga Thrust of Assam-Arakan basin. Northeastern India Environ Earth Sci 75:604. https://doi.org/10.1007/s12665-016-5372-4

Kume T, Akca E, Nakano T et al (2010) Seasonal changes of fertilizer impacts on agricultural drainage in a salinized area in Adana, Turkey. Sci Total Environ 408:3319-3326. https://doi.org/10.1016/j.scitotenv.2010.03.028

Lantagne DS (2008) Sodium hypochlorite dosage for household and emergency water treatment. J - Am Water Works Assoc 100:106-119. https://doi.org/10.1002/j.1551-8833. 2008.tb09704.x 
Lazur A, VanDerwerker T, Koepenick K (2020) Review of Implications of Road Salt Use on Groundwater QualityCorrosivity and Mobilization of Heavy Metals and Radionuclides. Water Air Soil Pollut 231:474. https://doi. org/10.1007/s11270-020-04843-0

Le Pape P, Ayrault S, Quantin C (2012) Trace element behavior and partition versus urbanization gradient in an urban river (Orge River, France). J Hydrol 472-473:99-110. https:// doi.org/10.1016/j.jhydrol.2012.09.042

Lee H, Cody RD, Cody AM, Spry PG (2000) Effects of various deicing chemicals on pavement concrete deterioration. Citeseer, pp 151-155

Leitzmann MF, Stampfer MJ, Wu K et al (2003) Zinc Supplement Use and Risk of Prostate Cancer. JNCI Journal of the National Cancer Institute 95:1004-1007. https://doi.org/ 10.1093/jnci/95.13.1004

LeMonte JJ, Stuckey JW, Sanchez JZ et al (2017) Sea Level Rise Induced Arsenic Release from Historically Contaminated Coastal Soils. Environ Sci Technol 51:5913-5922. https://doi.org/10.1021/acs.est.6b06152

Li P, Qian H, Howard KWF et al (2014) Anthropogenic pollution and variability of manganese in alluvial sediments of the Yellow River, Ningxia, northwest China. Environ Monit Assess 186:1385-1398. https://doi.org/10.1007/ s10661-013-3461-3

Li P, Qian H, Wu J et al (2014) Occurrence and hydrogeochemistry of fluoride in alluvial aquifer of Weihe River, China. Environ Earth Sci 71:3133-3145. https://doi.org/ 10.1007/s12665-013-2691-6

Likens GE (2010) The role of science in decision making: does evidence-based science drive environmental policy? Front Ecol Environ 8:e1-e9. https://doi.org/10.1890/090132

Likens GE (2013) Biogeochemistry of a Forested Ecosystem. Springer Science \& Business Media, New York

Likens GE, Bormann FH, Johnson NM et al (1970) Effects of Forest Cutting and Herbicide Treatment on Nutrient Budgets in the Hubbard Brook Watershed-Ecosystem. Ecol Monogr 40:23-47. https://doi.org/10.2307/1942440

Likens GE, Butler TJ, Claybrooke R et al (2021) Long-term monitoring of precipitation chemistry in the U.S.: Insights into changes and condition. Atmospheric Environment. https://doi.org/10.1016/j.atmosenv.2020.118031

Likens GE (2009) Encyclopedia of Inland Waters. Elsever, Amsterdam

Lopatina T, Anishchenko O, Oskina N, Zadereev E (2021) Threshold concentrations of the road salt for adverse effects on females and resting eggs of cladoceran Moina macrocopa. Aquat Ecol 55:283-297. https://doi.org/10. 1007/s10452-021-09830-z

Ludwig RD, Smyth DJA, Blowes DW et al (2009) Treatment of Arsenic, Heavy Metals, and Acidity Using a Mixed ZVICompost PRB. Environ Sci Technol 43:1970-1976. https://doi.org/10.1021/es802394p

Manning DAC (2015) How will minerals feed the world in 2050? Proceedings of the Geologists' Association 126:14-17. https://doi.org/10.1016/j.pgeola.2014.12.005

Maslia ML, Prowell DC (1990) EFFECT OF FAULTS ON FLUID FLOW AND CHLORIDE CONTAMINATION IN A CARBONATE AQUIFER SYSTEM. Journal of Hydrology 115:1-49
Maul GA, Kim Y, Amini A et al (2014) Efficiency and life cycle environmental impacts of ion-exchange regeneration using sodium, potassium, chloride, and bicarbonate salts. Chem Eng J 254:198-209. https://doi.org/10.1016/j.cej.2014.05. 086

Mayer B, Boyer EW, Goodale C et al (2002) Sources of nitrate in rivers draining sixteen watersheds in the northeastern U.S.: Isotopic constraints. Biogeochemistry 57:171-197. https://doi.org/10.1023/A:1015744002496

McClain CN, Fendorf S, Johnson ST et al (2019) Lithologic and redox controls on hexavalent chromium in vadose zone sediments of California's Central Valley. Geochim Cosmochim Acta 265:478-494. https://doi.org/10.1016/j.gca. 2019.07.044

McDevitt B, McLaughlin MC, Vinson DS et al (2020) Isotopic and element ratios fingerprint salinization impact from beneficial use of oil and gas produced water in the Western U.S. Science of The Total Environment. https://doi.org/10. 1016/j.scitotenv.2020.137006

McNaboe LA, Robbins GA, Dietz ME (2017) Mobilization of Radium and Radon by Deicing Salt Contamination of Groundwater. Water Air Soil Pollut 3:1-9. https://doi.org/ 10.1007/s11270-016-3227-y

McPherson CA, Lawrence GS, Elphick JR, Chapman PM (2014) Development of a strontium chronic effects benchmark for aquatic life in freshwater: Strontium aquatic benchmark. Environ Toxicol Chem 33:2472-2478. https:// doi.org/10.1002/etc. 2696

Meisler H (1989) The occurrence and geochemistry of salty ground water in the northern Atlantic Coastal Plain. Professional Paper. https://doi.org/10.3133/pp1404D

Menz FC, Seip HM (2004) Acid rain in Europe and the United States: an update. Environ Sci Policy 7:253-265. https:// doi.org/10.1016/j.envsci.2004.05.005

Meybeck M (1982) Carbon, Nitrogen, and Phosphorus Transport by World Rivers. Am J Sci 282:401-450

Meybeck M (2003) Global analysis of river systems: from Earth system controls to Anthropocene syndromes. Phil Trans R Soc Lond B 358:1935-1955. https://doi.org/10.1098/rstb. 2003.1379

Meybeck M, Helmer R (1989) The quality of rivers: from pristine stage to global pollution. Palaeogeogr Palaeoclimatol Palaeoecol 75:27

Meyer JL (1980) Dynamics of phosphorus and organic matter during leaf decomposition in a forest stream. Oikos 34:44. https://doi.org/10.2307/3544548

Mirzavand M, Ghasemieh H, Sadatinejad SJ, Bagheri R (2020) An overview on source, mechanism and investigation approaches in groundwater salinization studies. Int $\mathbf{J}$ Environ Sci Technol 17:2463-2476. https://doi.org/10. 1007/s13762-020-02647-7

Mohod C, Dhote J (2013) Review of heavy metals in drinking water and their effect on human health. International Journal of Innovative Research in Science, Engineering and Technology 2:2992-2996

Mokashi K, Shetty V, George SA, Sibi G (2016) Sodium Bicarbonate as Inorganic Carbon Source for Higher Biomass and Lipid Production Integrated Carbon Capture in Chlorella vulgaris. Achievements in the Life Sciences 10:111-117. https://doi.org/10.1016/j.als.2016.05.011 
Moore SJ, Bassett RL, Liu B et al (2008) Geochemical Tracers to Evaluate Hydrogeologic Controls on River Salinization. Groundwater 46:489-501. https://doi.org/10.1111/j.17456584.2007.00420.x

Moore J, Bird DL, Dobbis SK, Woodward G (2017) Nonpoint source contributions drive elevated major ion and dissolved inorganic carbon concentrations in urban watersheds. Environ Sci Technol Lett 4:198-204

Moore J, Fanelli RM, Sekellick AJ (2019) High-frequency data reveal deicing salts drive elevated specific conductance and chloride along with pervasive and frequent exceedances of the US Environmental Protection Agency aquatic life criteria for chloride in urban streams. Environ Sci Technol 54:778-789

Moran JE, Oktay SD, Santschi PH (2002) Sources of iodine and iodine 129 in rivers. Water Resources Research. https://doi. org/10.1029/2001WR000622

Morel CJ, Kaushal SS, Tan ML, Belt KT (2020) Developing Sensor Proxies for "Chemical Cocktails" of Trace Metals in Urban Streams. Water 12:2864

Morteau B, Triffault-Bouchet G, Galvez R, Martel L (2015) Nutrient and Removal Kinetics Impacts on Salt Phytoremediation by Atriplex patula and Typha angustifolia. J Environ Eng 141:04014059. https://doi.org/10.1061/ (ASCE)EE.1943-7870.0000889

Moyad MA (2004) Zinc for prostate disease and other conditions: a little evidence, a lot of hype, and a significant potential problem. Urol Nurs 24:4

Nassery HR, Kayhomayoon Z (2013) Source of salinity in the groundwater of Lenjanat Plain, Isfahan. Iran Environ Earth Sci 68:413-427. https://doi.org/10.1007/s12665-0121746-4

Neal C, Neal M, Hughes S et al (2007) Bromine and bromide in rainfall, cloud, stream and groundwater in the Plynlimon area of mid-Wales. Hydrol Earth Syst Sci 11:301-312. https://doi.org/10.5194/hess-11-301-2007

Newcomer Johnson TA, Kaushal SS, Mayer PM et al (2016) Nutrient retention in restored streams and rivers: a global review and synthesis. Water 8:116. https://doi.org/10. 3390/w8040116

Norrström AC, Jacks G (1998) Concentration and fractionation of heavy metals in roadside soils receiving de-icing salts. Sci Total Environ 218:161-174. https://doi.org/10.1016/ S0048-9697(98)00203-4

Novak JM, Cantrell KB, Watts DW et al (2014) Designing relevant biochars as soil amendments using lignocellulosic-based and manure-based feedstocks. J Soils Sediments 14:330-343. https://doi.org/10.1007/s11368-0130680-8

Novotny V, Muehring D, Zitomer DH et al (1998) Cyanide and metal pollution by urban snowmelt: Impact of deicing compounds. Water Sci Technol 38:223-230. https://doi. org/10.1016/S0273-1223(98)00753-7

Osborn SG, Vengosh A, Warner NR, Jackson RB (2011) Methane contamination of drinking water accompanying gas-well drilling and hydraulic fracturing. PNAS 108:8172-8176. https://doi.org/10.1073/pnas.1100682108

Ozsvath DL (2009) Fluoride and environmental health: a review. Rev Environ Sci Biotechnol 8:59-79. https://doi. org/10.1007/s11157-008-9136-9
Palmer MA, Bernhardt ES, Schlesinger WH et al (2010) Mountaintop mining consequences. Science 327:148-149

Passeport E, Vidon P, Forshay KJ et al (2013) Ecological engineering practices for the reduction of excess nitrogen in human-influenced landscapes: A guide for watershed managers. Environ Manage 51:392-413

Paul MJ, Coffey R, Stamp J, Johnson T (2019) A Review of Water Quality Responses to Air Temperature and Precipitation Changes 1: Flow, Water Temperature, Saltwater Intrusion. JAWRA Journal of the American Water Resources Association 55:824-843. https://doi.org/10. 1111/1752-1688.12710

Pieper KJ, Tang M, Edwards MA (2017) Flint Water Crisis Caused By Interrupted Corrosion Control: Investigating "Ground Zero" Home. Environ Sci Technol 51:2007-2014. https://doi.org/10.1021/acs.est.6b04034

Pieper KJ, Tang M, Jones CN et al (2018) Impact of Road Salt on Drinking Water Quality and Infrastructure Corrosion in Private Wells. Environ Sci Technol 52:14078-14087. https://doi.org/10.1021/acs.est.8b04709

Pillsbury AF (1981) The Salinity of Rivers. Sci Am 245:54-65

Piotrowski PK, Tasker TL, Geeza TJ et al (2020) Forensic tracers of exposure to produced water in freshwater mussels: a preliminary assessment of $\mathrm{Ba}, \mathrm{Sr}$, and cyclic hydrocarbons. Sci Rep 10:15416. https://doi.org/10.1038/ s41598-020-72014-6

Podgorski J, Berg M (2020) Global threat of arsenic in groundwater. Science 368:845-850. https://doi.org/10. 1126/science.aba1510

Potter J, McDowell W, Helton A, Daley M (2014) Incorporating urban infrastructure into biogeochemical assessment of urban tropical streams in Puerto Rico. Biogeochemistry 121:271-286

Praveen VV, Mathews AP, Karr GS (2007) Low-Cost Propionate and Acetate Salts as Road Deicer from Cheese Whey. World J Microbiol Biotechnol 24:825-832

Pulley AK, Baird K, Felsburg H (2010) Investigation of re-use options for used traction sand. Colorado. DTD Applied Research and Innovation Branch

Qasemi M, Farhang M, Biglari H et al (2018) Health risk assessments due to nitrate levels in drinking water in villages of Azadshahr, northeastern Iran. Environ Earth Sci 77:782. https://doi.org/10.1007/s12665-018-7973-6

Qdais HA, Moussa H (2004) Removal of heavy metals from wastewater by membrane processes: a comparative study. Desalination 164:105-110. https://doi.org/10.1016/S00119164(04)00169-9

Rahman MA, Reichman SM, De Filippis L et al (2016) Phytoremediation of Toxic Metals in Soils and Wetlands: Concepts and Applications. In: Rahman MA (ed) Hasegawa H, Rahman IMdM. Environmental Remediation Technologies for Metal-Contaminated Soils. Springer Japan, Tokyo, pp 161-195

Rakib MA, Sasaki J, Matsuda H et al (2020) Groundwater salinization and associated co-contamination risk increase severe drinking water vulnerabilities in the southwestern coast of Bangladesh. Chemosphere 246:125646. https:// doi.org/10.1016/j.chemosphere.2019.125646

Ramakrishna DM, Viraraghavan T (2005) Environmental Impact of Chemical Deicers - A Review. Water Air Soil 
Pollut 166:49-63. https://doi.org/10.1007/s11270-0058265-9

Rao N (2003) Fluoride and environment- a review. 15

Raymond PA, Cole JJ (2003) Increase in the export of alkalinity from North America's largest river. Science 301:88-91

Raymond PA, Oh N-H (2009) Long term changes of chemical weathering products in rivers heavily impacted from acid mine drainage: Insights on the impact of coal mining on regional and global carbon and sulfur budgets. Earth Planet Sci Lett 284:50-56

Raymond PA, Oh N-H, Turner RE, Broussard W (2008) Anthropogenically enhanced fluxes of water and carbon from the Mississippi River. Nature 451:449-452

Reid-Soukup DA, Ulery AL (2018) Smectites. Soil Mineralogy with Environmental Applications. Wiley, Madison, pp 467-499

Sánchez-Martos F, Pulido-Bosch A, Molina-Sánchez L, Vallejos-Izquierdo A (2002) Identification of the origin of salinization in groundwater using minor ions (Lower Andarax, Southeast Spain). Sci Total Environ 297:43-58. https://doi.org/10.1016/S0048-9697(01)01011-7

Schlesinger WH (2020) Some thoughts on the biogeochemical cycling of potassium in terrestrial ecosystems. Biogeochemistry. https://doi.org/10.1007/s10533-018-0452-z

Schmidt CW (2017) Another side of a low-salt diet: reductions in the salinity of drinking water may lower blood pressure. Environ Health Perspect 125:064002

Schoepfer VA, Bernhardt ES, Burgin AJ (2014) Iron clad wetlands: Soil iron-sulfur buffering determines coastal wetland response to salt water incursion. J Geophys Res Biogeosci 119:2209-2219. https://doi.org/10.1002/ 2014JG002739

Schuler MS, Relyea RA (2018) A review of the combined threats of road salts and heavy metals to freshwater systems. Bioscience 68:327-335. https://doi.org/10.1093/ biosci/biy018

Schuler MS, Cañedo-Argüelles M, Hintz WD et al (2019) Regulations are needed to protect freshwater ecosystems from salinization. Philos Trans R Soc B 374:20180019

Schunck H, Lavik G, Desai DK et al (2013) Giant Hydrogen sulfide plume in the oxygen minimum zone off peru supports chemolithoautotrophy. PLoS ONE 8:e68661. https:// doi.org/10.1371/journal.pone.0068661

Scott V, Juran L, Ling EJ et al (2020) Assessing strontium and vulnerability to strontium in private drinking water systems in virginia. Water 12:1053. https://doi.org/10.3390/ w12041053

Shaver K (2015) The snow brought out the salt, which caused Montgomery's brown water. In: The Washington Post. https://www.washingtonpost.com/local/montgomeryresidents-complain-about-brown-tap-water/2015/06/17/ d7910098-146c-11e5-9518-f9e0a8959f32_story.html. Accessed 22 Feb 2021

Shaw SB, Marjerison RD, Bouldin DR et al (2012) Simple model of changes in stream chloride levels attributable to road salt applications. J Environ Eng 138:112-118

Siener R, Jahnen A, Hesse A (2004) Influence of a mineral water rich in calcium, magnesium and bicarbonate on urine composition and the risk of calcium oxalate crystallization. Eur J Clin Nutr 58:270-276. https://doi.org/10.1038/sj. ejcn. 1601778
Singh AK, Mondal GC, Kumar S et al (2008) Major ion chemistry, weathering processes and water quality assessment in upper catchment of Damodar River basin, India. Environ Geol 54:745-758. https://doi.org/10.1007/ s00254-007-0860-1

Skowron P, Skowrońska M, Bronowicka-Mielniczuk U et al (2018) Anthropogenic sources of potassium in surface water: The case study of the Bystrzyca river catchment, Poland. Agr Ecosyst Environ 265:454-460. https://doi.org/ 10.1016/j.agee.2018.07.006

Smedley PL, Kinniburgh DG (2002) A review of the source, behaviour and distribution of arsenic in natural waters. Appl Geochem 17:517-568. https://doi.org/10.1016/ S0883-2927(02)00018-5

Snodgrass JW, Moore J, Lev SM et al (2017) Influence of modern stormwater management practices on transport of road salt to surface waters. Environ Sci Technol $51: 4165-4172$

Sprinkle CL (1989) Geochemistry of the Floridan aquifer system in Florida and in parts of Georgia, South Carolina, and Alabama. United States Geological Survey, Professional Paper; (USA) 1403-I:

Steele M, Aitkenhead-Peterson J (2011) Long-term sodium and chloride surface water exports from the Dallas/Fort Worth region. Sci Total Environ 409:3021-3032

Stephenson KM, Novakowski K, Davis E, Heron G (2006) Hydraulic characterization for steam enhanced remediation conducted in fractured rock. J Contam Hydrol 82:220-240. https://doi.org/10.1016/j.jconhyd.2005.10. 002

Stets EG, Kelly VJ, Crawford CG (2014) Long-term trends in alkalinity in large rivers of the conterminous US in relation to acidification, agriculture, and hydrologic modification. Sci Total Environ 488:280-289

Stets EG, Lee CJ, Lytle DA, Schock MR (2018) Increasing chloride in rivers of the conterminous U.S. and linkages to potential corrosivity and lead action level exceedances in drinking water. Sci Total Environ 613-614:1498-1509. https://doi.org/10.1016/j.scitotenv.2017.07.119

Stets EG, Sprague LA, Oelsner GP et al (2020) Landscape drivers of dynamic change in water quality of US rivers. Environ Sci Technol 54:4336-4343

Suaire R, Durickovic I, Framont-Terrasse L et al (2016) Phytoextraction of $\mathrm{Na}+$ and $\mathrm{Cl}-$ by Atriplex halimus $\mathrm{L}$. and Atriplex hortensis L.: A promising solution for remediation of road runoff contaminated with deicing salts. Ecol Eng 94:182-189. https://doi.org/10.1016/j.ecoleng.2016.05. 055

Subramani T, Rajmohan N, Elango L (2010) Groundwater geochemistry and identification of hydrogeochemical processes in a hard rock region, Southern India. Environ Monit Assess 162:123-137. https://doi.org/10.1007/ s10661-009-0781-4

Svingen T, Vinggaard AM (2016) The risk of chemical cocktail effects and how to deal with the issue. J Epidemiol Community Health 70:322-323. https://doi.org/10.1136/jech2015-206268

Szabo Z, Stackelberg PE, Cravotta CA (2020) Occurrence and geochemistry of lead-210 and polonium-210 radionuclides in public-drinking-water supplies from principal aquifers 
of the United States. Environ Sci Technol 54:7236-7249. https://doi.org/10.1021/acs.est.0c00192

Talling JF (2010) Potassium-a non-limiting nutrient in fresh waters? Freshwater Reviews 3:97-104. https://doi.org/10. 1608/FRJ-3.2.1

Tang L, Lindvall A (2012) Validation of models for prediction of chloride ingress in concrete exposed in de-icing salt road environment. International Journal of Structural Engineering 4:86-99. https://doi.org/10.1504/IJSTRUCTE. 2013.050766

Tang W, Kovalsky P, Cao B, Waite TD (2016) Investigation of fluoride removal from low-salinity groundwater by singlepass constant-voltage capacitive deionization. Water Res 99:112-121. https://doi.org/10.1016/j.watres.2016.04.047

Thomas SC, Frye S, Gale N et al (2013) Biochar mitigates negative effects of salt additions on two herbaceous plant species. J Environ Manage 129:62-68

Tiffany MA, Winchester JW, Loucks RH (1969) Natural and pollution sources of iodine, bromine, and chlorine in the great lakes. Water Pollution Control Federation 41:12

Tobiason JE, Bazilio A, Goodwill J et al (2016) Manganese removal from drinking water sources. Curr Pollution Rep 2:168-177. https://doi.org/10.1007/s40726-016-0036-2

Tokunaga TK, Wan J, Firestone MK et al (2001) Chromium diffusion and reduction in soil aggregates. Environ Sci Technol 35:3169-3174. https://doi.org/10.1021/ es010523m

Tost H (2017) Chemistry-climate interactions of aerosol nitrate from lightning. Atmos Chem Phys 17:1125-1142. https:// doi.org/10.5194/acp-17-1125-2017

Trabelsi R, Zairi M, Ben Dhia H (2007) Groundwater salinization of the Sfax superficial aquifer, Tunisia. Hydrogeol J 15:1341-1455. https://doi.org/10.1007/s10040-007-01820

National Research Council (US). Committee on the Comparative Costs of Rock Salt, Calcium Magnesium Acetate (CMA) for Highway Deicing (1991) Highway deicing: comparing salt and calcium magnesium acetate. Transportation Research Board

Trenberth KE, Smith L, Qian T et al (2007) Estimates of the global water budget and its annual cycle using observational and model data. J Hydrometeor 8:758-769. https:// doi.org/10.1175/JHM600.1

Tully K, Gedan K, Epanchin-Niell R et al (2019) The invisible flood: the chemistry, ecology, and social implications of coastal saltwater intrusion. Bioscience 69:368-378. https:// doi.org/10.1093/biosci/biz027

Tully KL, Weissman D, Wyner WJ et al (2019) Soils in transition: saltwater intrusion alters soil chemistry in agricultural fields. Biogeochemistry 142:339-356. https://doi.org/ 10.1007/s10533-019-00538-9

Uchimiya M, Lima IM, Klasson KT, Wartelle LH (2010) Contaminant immobilization and nutrient release by biochar soil amendment: Roles of natural organic matter. Chemosphere 80:935-940. https://doi.org/10.1016/j. chemosphere.2010.05.020

Ury EA, Anderson SM, Peet RK et al (2020) Succession, regression and loss: does evidence of saltwater exposure explain recent changes in the tree communities of North Carolina's Coastal Plain? Ann Bot 125:255-264. https:// doi.org/10.1093/aob/mcz039
USEPA (2002) Radionuclides in drinking water: A small entity compliance guide

USEPA (2003) Drinking Water Advisory: Consumer Acceptability Advice and Health Effects Analysis on Sodium

USEPA (2005) A regulator's guide to the management of radioactive residuals from drinking water treatment technologies

USEPA (2009) National primary drinking water regulations

Valdemarsen T, Quintana CO, Thorsen SW, Kristensen E (2018) Benthic macrofauna bioturbation and early colonization in newly flooded coastal habitats. PLoS ONE 13:e196097. https://doi.org/10.1371/journal.pone. 0196097

Van Meter RJ, Swan CM, Leips J, Snodgrass JW (2011) Road salt stress induces novel food web structure and interactions. Wetlands 31:843-851

Vengosh A (2005) Salinization and Saline. In: Vengosh A (ed) Environmental geochemistry. Elsevier, Amsterdam, p 333

Vengosh A, Kondash A, Harkness J et al (2017) The geochemistry of hydraulic fracturing fluids. Procedia Earth and Planetary Science 17:21-24

Vineis P, Chan Q, Khan A (2011) Climate change impacts on water salinity and health. Journal of Epidemiology and Global Health 1:5-10. https://doi.org/10.1016/j.jegh.2011. 09.001

Vinson DS, Schwartz HG, Dwyer GS, Vengosh A (2011) Evaluating salinity sources of groundwater and implications for sustainable reverse osmosis desalination in coastal North Carolina, USA. Hydrogeol J 19:981-994. https://doi. org/10.1007/s10040-011-0738-x

Virkutyte J, Sillanpää M (2006) Chemical evaluation of potable water in Eastern Qinghai Province, China: Human health aspects. Environ Int 32:80-86. https://doi.org/10. 1016/j.envint.2005.05.022

Vitale SA, Robbins GA, McNaboe LA (2017) Impacts of road salting on water quality in fractured crystalline bedrock. J Environ Qual 46:288-294. https://doi.org/10.2134/ jeq2016.10.0411

Walker WJ (1999) The potential contribution of urban runoff to surface sediments of the Passaic River: Sources and chemical characteristics. Chemosphere 38:363-377. https://doi.org/10.1016/S0045-6535(98)00186-6

Walraven N, van Os BJH, Klaver GTh et al (2014) The lead (Pb) isotope signature, behaviour and fate of traffic-related lead pollution in roadside soils in The Netherlands. Sci Total Environ 472:888-900. https://doi.org/10.1016/j.scitotenv. 2013.11.110

Weissman DS, Tully KL (2020) Saltwater intrusion affects nutrient concentrations in soil porewater and surface waters of coastal habitats. Ecosphere 11:e03041. https:// doi.org/10.1002/ecs2.3041

Wen X, Lu J, Wu J et al (2019) Influence of coastal groundwater salinization on the distribution and risks of heavy metals. Sci Total Environ 652:267-277. https://doi.org/10.1016/j. scitotenv.2018.10.250

Wessel BM, Rabenhorst MC (2017) Identification of sulfidic materials in the Rhode River subestuary of Chesapeake Bay. Geoderma 308:215-225. https://doi.org/10.1016/j. geoderma.2017.07.025

Wetzel R (2001) Limnology Lake and River Ecosystems. Academic Press, Third 
Wilkin RT (2008) Contaminant attenuation processes at mine sites. Mine Water Environ 27:251-258. https://doi.org/10. 1007/s10230-008-0049-1

Wilkin RT, Acree SD, Ross RR et al (2009) Performance of a zerovalent iron reactive barrier for the treatment of arsenic in groundwater: Part 1. Hydrogeochemical studies. J Contam Hydrol 106:1-14. https://doi.org/10.1016/j.jconhyd. 2008.12.002

Williams WD (1987) Salinization of rivers and streams. An important environmental hazard Ambio 16:180-185

World Health Organization (2010) Potassium in drinking-water Background document for development of WHO Guidelines for Drinking-water Quality

World Health Organization (2011) Hardness in Drinking-water Background document for development of WHO Guidelines for Drinking-water Quality

Wright MT, Belitz K (2010) Factors controlling the regional distribution of vanadium in groundwater. Groundwater 48:515-525. https://doi.org/10.1111/j.1745-6584.2009. 00666.x

Xie N, Shi X, Zhang Y (2017) Impacts of potassium acetate and sodium-chloride deicers on concrete. J Mater Civ Eng 29:04016229
Yamanaka M, Kumagai Y (2006) Sulfur isotope constraint on the provenance of salinity in a confined aquifer system of the southwestern Nobi Plain, central Japan. J Hydrol 325:35-55. https://doi.org/10.1016/j.jhydrol.2005.09.026

Zarei M, Raeisi E, Merkel BJ, Kummer N-A (2013) Identifying sources of salinization using hydrochemical and isotopic techniques, Konarsiah. Iran Environ Earth Sci 70:587-604. https://doi.org/10.1007/s12665-012-2143-8

Zekster I, Everett LG (2004) Groundwater Resources of the World and Their Use

Zhang X, Wang H, He L et al (2013) Using biochar for remediation of soils contaminated with heavy metals and organic pollutants. Environ Sci Pollut Res 20:8472-8483. https://doi.org/10.1007/s11356-013-1659-0

Zhao S, Feng C, Wang D et al (2013) Salinity increases the mobility of $\mathrm{Cd}, \mathrm{Cu}, \mathrm{Mn}$, and $\mathrm{Pb}$ in the sediments of Yangtze Estuary: Relative role of sediments' properties and metal speciation. Chemosphere 91:977-984. https://doi.org/10. 1016/j.chemosphere.2013.02.001

Publisher's Note Springer Nature remains neutral with regard to jurisdictional claims in published maps and institutional affiliations. 